\title{
Antitakeover Legislation and Accounting Conservatism: New Evidence
}

\author{
Shijun Cheng \\ Associate Professor of Accounting \\ Robert H. Smith School of Business \\ University of Maryland \\ College Park, MD 20742 \\ Phone: (301) 405-5481 \\ Fax: (301) 314-9414 \\ Email: shijun@umd.edu \\ Augustine Duru \\ Professor of Accounting \\ Kogod School of Business \\ American University \\ Washington, DC 20016 \\ Phone: (202)885-1937 \\ Fax: (202) 885-1992 \\ Email: aduru@american.edu \\ Yijiang Zhao \\ Associate Professor of Accounting \\ Kogod School of Business \\ American University \\ Washington, DC 20016 \\ Phone: (202) 885-1941 \\ Fax: (202) 885-1992 \\ Email:yzhao@american.edu
}

August 2016 


\title{
Antitakeover legislation and accounting conservatism: New evidence
}

\begin{abstract}
:
We examine the effect of second-generation state antitakeover laws (ATLs) on accounting conservatism. We adopt a novel methodology that corrects for selection bias resulting from firms' endogenous incorporation decision. Focusing on the period from when these ATLs became constitutional, we find a negative association between ATLs and conservatism. Our results suggest that ATLs decrease debtholder demand for conservatism by reducing agency costs of debt.

JEL Classifications: M41, G3, K2

Keywords: State Antitakeover Laws; Accounting Conservatism; Debtholder Demand; Agency Costs of Debt.
\end{abstract}




\section{Introduction}

Academic interest in the relation between corporate governance mechanisms and accounting conservatism generally examines this relation from the shareholder perspective. ${ }^{1}$ As a major type of capital providers, debtholders play a crucial role in affecting accounting conservatism, which has been demonstrated in prior studies (e.g., Ahmed et al., 2002; Watts, 2003; Zhang, 2008; Ball et al., 2008a and 2008b; Nikolaev, 2010). Yet the impact of governance on debtholders' demand for conservatism has received little attention in the academic literature. A major reason is that many governance mechanisms such as family ownership (e.g., Anderson and Reeb, 2003; Anderson et al., 2003) and board monitoring (e.g., Klein, 2002; Anderson et al., 2004) protect both shareholder and debtholder interests, making it difficult to differentiate between these two perspectives. Takeover market monitoring, however, is one exception. As prior literature suggests, takeover defenses such as state antitakeover laws (ATLs), though weakening shareholder monitoring of managers (Bertrand and Mullainathan, 2003), can better protect debtholder interests (Francis et al., 2010). Therefore, utilizing the unique, differential effects of takeover defenses on shareholder versus debtholder interests, our study attempts to examine whether and how ATLs affect accounting conservatism.

Based on Watts' (2003) contracting explanation for conservatism, we develop two competing arguments for the impact of ATLs on conservatism, namely the "shareholder demand" view and the "debtholder demand" view. According to the "shareholder demand" view, conservatism facilitates efficient contracting between managers and shareholders in the presence

\footnotetext{
${ }^{1}$ In this paper, accounting conservatism refers only to conditional conservatism (Ball and Shivakumar, 2005; Beaver and Ryan, 2005), which involves a higher degree of verification imposed for recognizing good news as gains than for recognizing bad news as losses in financial statements (e.g., Basu, 1997; LaFond and Watts, 2008). We interchangeably use the terms "accounting conservatism," "conservatism," and "conditional conservatism" in this paper.
} 
of agency problems (Ball, 2001; Watts, 2003). As the severity of manager-shareholder conflicts increases with takeover defenses (e.g., Faleye, 2007; Masulis et al., 2007; Cheng and Indjejikian, 2009), shareholders would demand more conservatism as a substitute shareholder governance mechanism to constrain management's opportunistic behavior such as excess compensation payments and inefficient investments (Watts 2003). According to this view, we expect a firm's choice of accounting conservatism to increase with the strength of ATLs.

According to the debtholder demand view, accounting conservatism is shaped more by debtholders than by shareholders (Ball et al., 2008b). Conservatism is beneficial to debtholders by curtailing excessive payments of dividends to shareholders and more quickly transferring decision rights to debtholders (e.g., Ahmed et al., 2002; Watts 2003; Ball and Shivakumar, 2005), leading to lower agency costs of debt. Meanwhile, another stream of research (e.g., Chava et al., 2008; Francis et al., 2010) suggests that takeover defenses such as ATLs play a similar role in mitigating shareholder-debtholder conflicts. Therefore, stronger ATLs provide better protection for the interests of debtholders, thereby reducing their demand for conservatism. On the contrary, as weaker ATLs tend to induce managers to make decisions that benefit shareholders at the cost of debtholders (Francis et al., 2010), debtholders would likely demand higher conservatism to protect their interests. Taken together, this view predicts a negative association between the strength of ATLs and accounting conservatism.

Unlike prior ATL studies that generally assume that ATLs are exogenous to firms and thus adopt a difference-in-differences (DiD) design, we follow recent studies (e.g., Wald and Long, 2007) and adopt a two-stage methodology, which is characterized by the following three features. First, using a Heckman-type regression model, we control for the endogeneity in firms' incorporation decision and the resulting state ATLs to which the firms are subject. Recent studies 
(e.g., Bebchuk and Cohen, 2002; Wald and Long, 2007) find that firms whose home states have more ATLs are more likely to incorporate in their home states. Hence, to the extent that firms tend to incorporate in states with more ATLs, a firm's state of incorporation and the ATLs of the state cannot be taken as exogenous. Second, as in Wald and Long (2007) and Zhao et al. (2013), this design differentiates between the effect of ATLs on corporate outcomes in two regimes: home-state incorporation and out-of-state incorporation. Firms in the two regimes differ in several important aspects including their ability to receive favorable treatments in corporate law issues from state of incorporation public officials (Bebchuk and Cohen, 2003; Wald and Long, 2007). Consistent with this notion, prior studies (e.g., Wald and Long, 2007; Zhao et al., 2013) find that ATLs have differential effects in these two groups. A regression on the pooled sample without discriminating between these two regimes is likely to lack statistical power. Finally, because firms are more likely to factor in ATLs into various corporate decisions after ATLs were deemed constitutional, this methodology focuses on the period that begins in 1987 when the constitutionality of ATLs was finally resolved. This more recent sample period allows us to better account for firms' self-selection for more ATLs.

We examine the effect of ATLs on conservatism using a sample of 32,246 firm-year observations during the period 1987 - 2011. Following recent studies (e.g., Wald and Long, 2007; Zhao et al., 2013), we use Bebchuk and Cohen's (2003) index of ATLs, which is the number of ATLs adopted in the state-year in which the firm is incorporated. We measure accounting conservatism by the Basu (1997) model and control for various determinants of conservatism.

We first analyze whether firms incorporated in states with more ATLs choose higher or lower levels of conservatism. Distinct from prior literature (Jayaraman and Shivakumar, 2013), 
we find no significant association between the ATL index and accounting conservatism after the constitutionality of ATLs was resolved. ${ }^{2}$ We then endogenize firms' choice about whether to incorporate in their home state. Consistent with prior studies (e.g., Bebchuk and Cohen, 2003; Wald and Long, 2007; Zhao et al., 2013), we find that firms tend to incorporate in their home state if the state has adopted more ATLs. This suggests that the resulting ATLs which the firms are subject to are likely endogenous. After partitioning our sample by whether firms are incorporated in home states and correcting for potential bias resulting from endogenous incorporation decisions, we find that conservatism decreases with the ATL index in out-of-state incorporated firms, suggesting that ATLs indeed reduce conservatism. We do not find such results in firms that are incorporated in their home state. Our results are robust to a number of alternative specifications including an alternative sample period, additional control variables, and alternative measures of conservatism and antitakeover laws. In sum, our results in out-of-state firms are consistent with the prediction of the debtholder demand view. ${ }^{3}$

A possible interpretation for the differential results between the two regimes is that, unlike the incumbent managers of home-state incorporated firms who are more likely to benefit from local favoritism, those of out-of-state incorporated firms are less likely to receive such favorable treatment with respect to ATLs-related issues (e.g., Bebchuk and Cohen, 2003). Accordingly, to the extent that managers of out-of-state firms are less entrenched by ATLs, they are thus less likely to engage in self-dealing (e.g., empire building and overcompensation) which hurts shareholder value. In other words, the potential downside of ATLs is likely less harmful to

\footnotetext{
${ }^{2}$ Similarly, Wald and Long's (2007) finding in a plain-vanilla regression that does not account for endogenous incorporation decisions also suggests that state ATLs do not impact corporate behavior after 1987.

${ }^{3}$ As discussed in section 2.3, an opposing view, the shareholder demand view, predicts a positive association between ATLs and accounting conservatism, because ATLs increase the agency conflict between shareholders and managers (e.g., Cheng and Indjejikian, 2009), leading to higher shareholder demand for accounting conservatism (Watts, 2003).
} 
shareholders of out-of-state firms. Therefore, shareholder demand for conservatism to address ATLs-associated agency problems is relatively weaker for out-of-state firms, relative to homestate firms. On the other hand, prior accounting and finance literature (e.g., Klock et al. 2005; Ashbaugh-Skaife et al., 2006; Chava et al. 2008; Cremers et al., 2007; Francis et al., 2010) generally suggests that stronger takeover protection better safeguards debtholder interests. ${ }^{4}$ Therefore, debtholder demand for conservatism would decrease in the presence of stronger ATLs. Given that accounting conservatism per se is a costly tool for shareholders and managers (e.g., Roychowdhury, 2010; Chen et al., 2013), out-of-state firms (and their management), when subject to stronger ATLs, would tend to adopt lower conservatism without facing significant resistance by shareholders. In comparison, in home-state incorporated firms where the potential downside of ATLs (e.g., exacerbating self-dealing) is relatively severe to shareholders, such switch to lower conservatism is more likely to be resisted by shareholders.

Our results are contrary to Jayaraman and Shivakumar's (2013) (hereafter, JS) findings that ATLs lead to higher conservatism. They interpret their findings as evidence that aggravated agency costs of debt brought upon by the passage of the laws drive the increase in conservatism. Although informative, the findings in JS are not consistent with the majority of prior finance literature. In particular, several studies (e.g., Klock et al. 2005; Ashbaugh-Skaife et al., 2006; Chava et al. 2008; Cremers et al., 2007; Francis et al., 2010) suggest that takeover protection mitigates, rather than exacerbates, agency conflicts between shareholders and debtholders. ${ }^{5}$ This

\footnotetext{
${ }^{4}$ It is true that as takeover protection entrenches management and exacerbates managerial self-dealing (e.g., empire building), it is also likely to increase the firm's default risk, thus leading to higher costs of debt. Prior finance studies (e.g., Klock et al. 2005; Chava et al. 2008; Cremers et al., 2007; Francis et al., 2010), however, generally find lower costs of debt for firms with stronger takeover protection. These studies suggest that the net effect of stronger takeover protection is beneficial to debtholders.

${ }^{5} \mathrm{Qiu}$ and $\mathrm{Yu}(2009)$ also examine the effect of the passage of BC laws on the cost of debt. One of their main results is that, after the passage of $\mathrm{BC}$ laws, there was a significant increase in the yield spread for speculative-grade firms (a small portion of their sample), but there was no such increase for investment-grade firms. Thus, it is possible that
} 
in turn leads to lower costs of bonds (e.g., Francis et al., 2010) and lower costs of bank loans (e.g., Chava et al., 2008). If the inference of these studies holds, agency costs of debt should not be a driving force leading to JS' result of higher conservatism after the passage of ATLs.

Moreover, in using the Basu (1997) measure to gauge conservatism, JS includes year dummies as standalone terms rather than interact these dummies with the Basu elements in their augmented Basu model. Therefore, this model specification controls for secular changes, not in conservatism, but in earnings (the dependent variable of the Basu model). As Basu (1997) and Givoly and Hayn (2000) note, accounting conservatism has increased steadily from late 1970s to 1990s due to institutional changes such as increases in auditor legal liability exposure. Without controlling for such economy-wide trends in conservatism contemporaneous with ATLs, the estimates of JS regressions can potentially be biased by also capturing the effect of this trend.

To confirm this notion, we first replicate JS' results. Without controlling for time effects, we find a positive and significant effect of ATLs on conservatism over the period from 1976 to 1995, as in JS. We then add the interaction terms of year dummies and the Basu elements to the model in order to control for temporal increases in conservatism over the period. This DiD model accommodates the staggered passage of ATLs, treating all firms incorporated in states not passing a law in a year as the control group for a law passed in that year (Bertrand and Mullainathan, 1999 and 2003). We find that post-passage increases in conservatism, which are documented in JS, disappear in this model. Therefore, the positive association between ATLs and conservatism in JS is likely to be spurious due to the lack of control for economy-wide trends in conservatism.

for speculative-grade firms, debtholders would call for more conservatism to reduce the increased agency costs of debt. However, Francis et al. (2010) find that state ATLs are associated with lower bond yields for both investmentgrade and speculative-grade firms. Therefore, whether debtholders will demand higher conservatism in speculativegrade firms subject to more ATLs also remains an empirical issue. 
Our study makes two important contributions to the literature. First, we contribute to the large literature on the relation between various governance mechanisms and financial reporting quality in general (e.g., Byard et al., 2006; Koh, 2007; Clatworthy and Reel, 2013; Wang and Hussainey, 2013; Adut et al., 2013; Zhao et al., 2012), and the strand of literature that relates governance to accounting conservatism in particular (e.g., Ahmed and Duellman, 2007; LaFond and Roychowdhury, 2008; Jenkins and Velury, 2008; Garcia Lara et al., 2009; Li, 2010). With the exception of JS, these studies generally examine the role of governance from shareholders' perspective. The differential impact of takeover threat on shareholders' and debtholders' interests, as suggested in prior finance literature, motivates us to examine the relation between governance and conservatism from both shareholders' and debtholders' perspectives. To the best of our knowledge, we are the first to find that conservatism decreases with ATLs, suggesting a substitutive relation between conservatism and takeover protection in mitigating agency costs of debt.

Second, we also contribute to the ample literature that investigates the effects of legislation or regulatory reforms on corporate policies (e.g., Jeanjean and Stolowy, 2008; Kalelkar and Nwaeze, 2011; Doukakis, 2014; Hansen et al., 2014; Chen et al, 2014; Brown et al., 2014). Specifically, we contribute to the strand of literature that examines the impact of state ATLs on corporate policies and decisions. Prior studies document that antitakeover laws are associated with worker wages (Bertrand and Mullainathan, 1999), firms' productivity and profitability (Bertrand and Mullainathan, 2003), managerial ownership (Cheng et al., 2005), executive compensation (Cheng and Indjejikian, 2009), employee ownership in defined contribution plans (Rauh, 2006), financial leverage (Garvey and Hanka, 1999; Wald and Long, 2007), cost of debt financing (Francis et al., 2010), earnings management (Zhao and Chen, 
2009), voluntary disclosure (Zhao et al., 2013), and external information environment (Armstrong et al., 2012). We complement this stream of studies by providing evidence consistent with the notion that state ATLs are associated with a lower demand for conditional conservatism through their enhancing effect on debtholder interests of the firm.

Our findings have implications for public policy. In common-law economies such as the US, corporate governance is intended primarily to protect shareholder interests from managerial self-dealing behavior. Post-Enron reforms such as the Sarbanes-Oxley Act of 2002 and various rules released by the SEC are examples of this shareholder-oriented approach. However, to the extent that the interests of shareholders and debtholders are not entirely aligned, governance reforms that aim to benefit shareholders may turn out to harm debtholders. This is particularly true for those reforms that reduce directors' protection from takeover markets by increasing shareholders' access to the nomination process of the board. ${ }^{6}$ As prior studies (e.g., Berger et al. 1997; Cremers et al. 2007) suggest, takeover protection, though entrenching management and harming shareholders, instead benefits debtholders by reducing the variance of cash flow from operations and thus reducing the default risk of the firm. Focusing on state ATLs, our study further suggests that public policies that aim to increase takeover protection impact accounting conservatism, not through its effect on shareholder interests, but through its effect on debtholder interests. Policy makers need to be aware of the impact of governance reforms on debtholder interests when they consider and design such policies.

\footnotetext{
${ }^{6}$ For example, in 2010, the SEC adopted new Rule 14a-11 that required companies to include shareholdernominated directors in their proxy materials, subject to certain requirements. However, shortly after this adoption, the US Chamber of Commerce and the Business Roundtable sued the SEC to invalidate 14a-11. On July 22, 2011, the DC Circuit agreed with the Business Roundtable and vacated this new rule. Therefore, the reforms intended to empower shareholders and thus reduce takeover protection have encountered tremendous opposition. It is difficult to directly examine the impact of such intended reforms. As the debate remains active, our study's results also have important policy implications in this sense.
} 
Although this study contributes to the debate on the relation between corporate governance and conservatism, its evidence should be interpreted within the context of the following caveats. First, the possibility exists that the instruments we use to model a firm's incorporation choice may not be fully exogenous in a sense that they may be correlated with other relevant state-level factors. Second, our conclusions depend on the model specification that includes a large number of interactions as the determinants of conservatism, and thus may potentially result in unreliable inferences. Finally, JS' argument is likely to apply to those firms where debtholders have more power and thus may demand higher conservatism in the presence of stronger ATLs. Because our study focuses mostly on a novel methodology in testing the effect of ATLs on conservatism, we leave the identification of this atypical subset of firms to future research.

The rest of this paper is organized as follows. In Section 2, we discuss some related literature and present our testable hypotheses. In Section 3, we describe our research design that corrects for the endogeneity of firms' incorporation decisions. In Section 4, we report the results of baseline tests and various sensitivity tests. In Section 5, we demonstrate the importance of controlling for time effects in the difference-in-differences design. Finally, we summarize and conclude in Section 6.

\section{Literature review and hypothesis development}

\subsection{Shareholder demand and debtholder demand for accounting conservatism}

From shareholders' perspective, a burgeoning research has examined the role of conservatism in mitigating the conflict between managers and shareholders. For example, Watts (2003) argues that accounting conservatism prevents excess managerial compensation by 
requiring higher verification standards for profits relative to losses. According to Ball (2001), this important feature of conservatism hinders the ability of managers to overstate earnings to cover negative NPV projects, which in turn allows shareholders to better identify negative NPV projects and ultimately mitigate overinvestment. Other studies (e.g., Ahmed and Duellman, 2007; LaFond and Roychowdhury, 2008; Garcia Lara et al., 2009) further examine the relation between various governance mechanisms and conservatism. For example, LaFond and Roychowdhury (2008) argue that declining managerial ownership increases the severity of agency problems between managers and shareholders. Consistent with shareholders demanding increased conservatism in the presence of lower managerial ownership, they document that accounting conservatism is negatively associated with managerial ownership.

Yet, from debtholders' perspective, numerous studies (e.g., Ahmed et al., 2002; Watts, 2003; Bushman and Piotroski, 2006; Beatty et al., 2008; Zhang, 2008; Nikolaev, 2010) suggest that conservatism mitigates the conflict between creditors and borrowers. Because managers are less forthcoming about bad news than good news, creditors are expected to demand conservatism which not only reduces information asymmetry between creditors and borrowers, but also enhances debt contract efficiency by facilitating early transfer of control rights from borrowers to creditors (e.g., Ball and Shivakumar, 2005). Consistent with conservatism mitigating agency costs of debt related to dividend policy, Ahmed et al. (2002) find that conservatism reduces agency conflicts over dividend policy resulting in lower costs of debt financing. Zhang (2008) further documents that conservatism is associated with lower interest rates. Using a cross-country research design, Ball et al. (2008b) suggest that debt markets, not equity markets, are primarily responsible for conditional conservatism. In addition, focusing on the role played by conservatism in reducing information asymmetry between lead arrangers and 
other syndicate members of syndicated loans, Ball et al. (2008a) find that the proportion of the loans retained by lead arrangers for incentive purposes decreases with conservatism. Collectively, these studies suggest that debt contracting demand affects conservatism.

\subsection{Hypothesis development}

Prior literature suggests two competing views regarding the effect of ATLs on accounting conservatism. According to the "shareholder demand" view that focuses on the role of conservatism in mitigating the agency conflict between managers and shareholders, conservative reporting becomes more important to shareholders as the agency costs of equity increases. On one hand, prior literature (e.g., Karpoff and Malatesta, 1989; Bertrand and Mullainathan, 2003) suggests that takeover protection such as ATLs is likely to entrench incumbent managers and thus exacerbates the agency conflict between managers and shareholders. The heightened agency problems include but are not limited to higher levels of executive compensation (e.g., Cheng and Indjejikian, 2009) and a larger amount of inefficient, empire-building acquisitions (e.g., Gompers et al., 2003; Masulis et al., 2007). On the other hand, accounting conservatism serves as a governance mechanism that reduces managers' ability to engage in such behaviors (e.g., Ball, 2001; Watts, 2003). In addition, because conservatism provides verifiable information, it facilitates the monitoring of management and thus reduces stealing, earnings manipulation and the retention of incompetent managers. Therefore, to the extent that the shareholder demand for conservatism increases with the severity of agency problems between managers and shareholders, the shareholder demand view predicts a positive association between accounting conservatism and takeover protection provided by ATLs. 
The other view, the "debtholder demand" view, posits that accounting conservatism is shaped more by debtholders than by shareholders (Ball et al., 2008b). According to this view, ATLs and conservatism play a similar role in mitigating agency costs of debt. Predominant finance research (e.g., Klock et al. 2005; Chava et al. 2008; Cremers et al., 2007; Francis et al., 2010) generally suggests that antitakeover protection mitigates, rather than exacerbates, agency conflicts between shareholders and debt-holders. For example, Chava et al (2008) find that firms with higher takeover defenses are associated with lower costs of bank loans. Similarly, prior studies on accounting conservatism (e.g., Ahmed et al., 2002; Beatty et al., 2008; Zhang, 2008; Nikolaev, 2010) also suggest that conservatism lowers agency costs of debt. Given that ATLs and conservatism perform similar functions, they are likely to substitute for each other in protecting debtholder interests. Thus, as debtholders need less conservatism in the presence of stronger ATLs, this view predicts a negative association between conservatism and ATLs.

That said, one may argue that, even in the presence of stronger ATLs, managers may still choose higher conservatism in order to cater to higher shareholder demand for this accounting attribute, because debtholder interests are not hurt by higher conservatism. This argument indeed builds upon an assumption that shareholders prefer higher conservatism to lower conservatism in order to better safeguard their interests. However, conservatism per se potentially is a costly tool to shareholders as well as to managers. ${ }^{7}$ For example, conservatism may engender costs for shareholders and managers by making firms more susceptible to debt covenant violations, even in the absence of financial problems (e.g., Chen et al., 2013). More importantly, conservatism may also cause managers to avoid riskier value-adding projects and thus result in

\footnotetext{
${ }^{7}$ In a recent paper, Sunder (2016) discusses the trade-offs associated with attributes of financial reporting including conservatism.
} 
underinvestment problems (e.g., Roychowdhury 2010). ${ }^{8}$ This in turn hurts shareholder interests. Therefore, given these potential costs to shareholder interests, as well as the trade-offs associated with conservatism (Sunder 2016), we argue that shareholders do not always prefer higher conservatism for the protection of shareholder interests. Yet, according to the debtholder demand view, debtholders are the driving force for conservatism. Thus, when debtholder demand for conservatism is lower in the presence of stronger ATLs, firms (and their management) would tend to adopt lower conservatism without facing significant resistance by shareholders.

Given the foregoing competing arguments, whether either of the hypothesized views will dominate is ultimately an empirical question. Thus, we summarize these arguments in the following hypothesis, stated in null form:

Hypothesis 1: State ATLs are not associated with the degree of conservatism.

\section{Research design}

\subsection{Main characteristics of the methodology}

To investigate the impact of ATLs on conservatism, we follow the methodology adopted in Wald and Long (2007) and Zhao et al. (2013), which is characterized by the following three important aspects.

First, the methodology directly accounts for the endogeneity of firms' incorporation choice. Adopting a DiD research design, a majority of prior studies on the effect of ATLs (e.g., Bertrand and Mullainathan, 1999 and 2003) generally assume that the passage of state ATLs is exogenous to firms incorporated in the state. However, given that US firms can choose which

\footnotetext{
${ }^{8}$ Conservatism may also help reduce underinvestment in certain settings. For example, Garcia Lara et al., (2016) find that in settings where underinvestment is more likely, more conservative firms invest more in prudent projects and issue more debt, suggesting that conservatism encourages low-risk, positive-NPV investments.
} 
state to incorporate in and are thus subject to that state's ATLs, such ATLs are not exogenous. In particular, Bebchuk and Cohen (2003) find that, firms whose home states have more ATLs are more likely to incorporate in their home states, suggesting that firms self-select themselves into incorporation in certain states for protection by more ATLs. As Bebchuk (1992) further notes, because US firms can reincorporate with relative ease, in any given period of time, each firm makes either an explicit reincorporation decision or an implicit decision to remain in the current state. Thus, a model that ignores such self-selection of incorporation and the resulting endogeneity of the state of incorporation's ATLs may yield biased estimates of ATLs' effects on an outcome variable such as conservatism.

Second, as in prior literature (e.g., Wald and Long, 2007), we use an endogenous switching regression model (Maddala, 1986), which allows the effect of ATLs to differ between two regimes: home-state incorporation and out-of-state incorporation. Prior studies (e.g., Bebchuk and Cohen, 2003; Wald and Long, 2007) find that firms of the two regimes differ in several important aspects such as firm size and the number of employees. In particular, Bebchuk and Cohen (2003) suggest that, compared with those out-of-state incorporated firms, firms incorporated in their home states have stronger local connections with public officials of their state of incorporation, allowing these firms to receive favorable treatments in corporate law issues and other legal issues from local officials. Therefore, the effect of state ATLs is likely to differ between these two regimes. Consistent with this notion, prior ATL studies (e.g., Wald and Long, 2007; Zhao et al., 2013) find that the effects of ATLs on various corporate outcomes such as financial leverage and voluntary disclosure differ significantly between these regimes.

Third, consistent with Wald and Long (2007) and Zhao et al. (2013), the sample period under this methodology starts in 1987, the year in which the Supreme Court ruled second- 
generation ATLs to be constitutional in CTS v. Dynamics Corp. ${ }^{9}$ Compared with earlier years, ATLs are likely to have become a more important factor in determining firms' incorporating choice and other behavior from this year onward. Therefore, this more recent sample period facilitates the use of a two-stage method to directly account for firms' self-selection for more ATLs. In addition, another key advantage of focusing on this recent period is that we can conveniently retrieve historical incorporation data from the RiskMetrics database. ${ }^{10}$ Also note that states rarely passed new ATLs after late 1980s. Thus, unlike the difference-in-differences methodology that relies on cross-period variation in state-level takeover protection surrounding the passage of ATLs (e.g., Bertrand and Mullainathan, 1999), this methodology focuses primarily on cross-sectional variation in the number of ATLs adopted in each state. Below we detail the model specification of this methodology.

\subsection{Heckman's two-stage self-selection model}

\subsubsection{Endogenous incorporation decision: first-stage regression}

In the first stage of the Heckman-type model (e.g., Maddala, 1986), we follow recent studies (e.g., Bebchuk and Cohen, 2003; Wald and Long, 2007) and estimate the likelihood of a firm's incorporation decision in Equation (1):

$$
\begin{aligned}
\text { HomeState }_{i t} & =\alpha_{0}+\alpha_{1} \text { Home StateLawIndex }_{i t}+\alpha_{2} \text { Home TAconstraint }_{i t} \\
& +\alpha_{3} \text { Log }(\text { OperatingStates })_{i t}+\alpha_{4} \text { Home-state Employment }_{i t} \\
& +\sum \alpha_{m} \text { Other control variable } \text { Fit }_{i t}+u_{i t}
\end{aligned}
$$

\footnotetext{
${ }^{9}$ In Section 4.2, we also expand our sample period up to 1982, the year in which the first second-generation ATL (a CSA law) was adopted in Ohio. Our results remain essentially unchanged.

${ }^{10}$ The RiskMetrics database, whose initial coverage starts in 1990, ensures that each observation in our tests is assigned with its proper state of incorporation via historical information on firms' incorporation. We extrapolate the RiskMetrics data from 1990 to 1987 by assuming that firms did not change their state of incorporation over this short period. By comparison, Compustat only provides data on firms' current state of incorporation.
} 
In this equation, HomeState is a dummy variable that reflects the binary outcome of whether the firm incorporates in its home state or out-of-state. We include various state and firm characteristics to serve as predictors of the incorporation choice. Specifically, similar to Wald and Long (2007) and Zhao et al. (2013), we control for measures of home state's antitakeover statutes and payout restrictions (i.e., Home StateLawIndex and Home TAconstraint) to capture the effect of these state laws on firms' incorporation decisions. The determinants based on firm characteristics include firm size (Log(FirmSize)), growth opportunity $(M / B, R \& D \%$ and $A d v E x p \%)$, asset tangibility (PP\&E\%), investment cycle (DepExp\%), institutional ownership (InstiOwn\%), geographic dispersion (Log(OperatingStates)), and in-state employment (Homestate Employment). ${ }^{11}$ We also include a set of industry and year dummies to control for industry and year fixed effects. We define these variables in detail in Table 1.

The implementation of the Heckman two-stage procedure requires the presence of at least one instrumental variable (IV) that is correlated with the dependent variable in the first-stage equation (i.e., the endogenous incorporation choice), but is not correlated with the second-stage error term. We use two variables, geographic dispersion ( $\log ($ OperatingStates $))$ and in-state employment (Home-state Employment), as our IVs. ${ }^{12}$ Following Garcia and Norli (2012), we measure a firm's geographic dispersion as the number of U.S. states mentioned in the annual report filed on Form 10-K with the SEC. We take the natural log of this raw measure to construct our metric of geographic dispersion (Log(OperatingStates)). A higher value of this measure indicates higher (lower) geographic dispersion (concentration). The calculation of home-state

\footnotetext{
${ }^{11}$ The first-stage model does not include FinPerf as a control variable, because FinPerf is the dependent variable of the Basu measure in the second-stage regression.

${ }^{12}$ As discussed below, we control for state of location fixed effects in the second-stage conservatism equation (i.e., Equation (2) of our paper). Accordingly, HomeStateLawIndex and HomeTAconstraint, which capture the legal environment of the firm's state of location, are subsumed within these state dummies; thus, they are not used as instrumental variables.
} 
employment calls for information on the number of a firm's employees in its home state. We use a firm's total number of employees divided by its number of operating states as a proxy for the number of its home-state employees. We then measure home-state employment (Home-state Employment) by the ratio of the firm's home-state employees to its home-state population.

These two variables are valid IVs for the following reasons. First, as Bebchuk and Cohen (2003) argue (but do not test), the more concentrated a firm's operations are in its home state, the more likely the firm is to incorporate in its home state. Thus, geographically dispersed firms are less likely to incorporate in their home state. Second, state legislatures generally respond to instate organized employees, who vote in state elections, more than out-of-state dispersed shareholders, who do not vote in such elections (Romano 1987). Accordingly, a firm with a higher level of in-state employment would have greater ability to seek protective legislation in the state. Thus, such firms are more likely to incorporate in-state (Bebchuk and Cohen, 2003). Finally, it is unlikely that $\log$ (OperatingStates) and Home-state Employment affect accounting conservatism, because according to the conservatism literature (e.g., Watts 2003), the major firm-level determinants of conservatism are contracts (including debt and compensation contracts), litigation, taxation, and regulation. ${ }^{13}$ Given that these two variables are likely to drive firms' incorporation choice, but are unlikely to affect accounting conservatism, we believe that they are valid instruments for the incorporation decision.

\subsubsection{ATLs and conservatism: second-stage analysis}

The second-stage analysis of the endogenous switching regression model allows all coefficients on explanatory variables to differ between the regime where firms are incorporated

\footnotetext{
${ }^{13}$ Khan and Watts (2009) further use market-to-book, firm size, and leverage as summary measures of the four factors.
} 
in their home states and the regime where firms are incorporated out-of-state. ${ }^{14} \mathrm{We}$ compute inverse Mills ratios $\left(\right.$ InvMills $_{0, \text { it }}$ for HomeState Ht $=0$ and InvMills $_{1, \text { it }}$ for HomeState Ht $\left.=1\right)$ based on the results from Equation (1), and include the interactions between these ratios and the Basu (1997) elements as additional control variables in the following second-stage Equation (2):

$$
\begin{aligned}
\text { Earn }_{i t} & =\beta_{j, 0}+\beta_{j, 1} \text { Return }_{i t}+\beta_{j, 2} \text { Neg }_{i t}+\beta_{j, 3} \text { Return }_{i t} * \text { Neg }_{i t}+\beta_{j, 4} \text { StateLawIndex }_{i t} \\
& +\beta_{j, 5} \text { StateLawIndex }_{i t} \text { Return }_{i t}+\beta_{j, 6} \text { StateLawIndex }_{i t} * \text { Neg }_{i t} \\
& +\beta_{j, 7} \text { StateLawIndex }_{i t} * \text { Return }_{i t} * \text { Neg }_{i t}+\beta_{j, 8} \text { InvMills }_{j, i t}+\beta_{j, 9} \text { InvMills }_{j, i t} * \text { Return }_{i t} \\
& +\beta_{j, 10} \text { InvMills }_{j, i t} * \text { Neg }_{i t}+\beta_{j, I I} \text { InvMills }_{j, i t} * \text { Return }^{*} \text { Neg }_{i t}+\sum \varphi_{j, m} \text { Control variable }_{m, i t} \\
& +\sum \lambda_{j, m} \text { Control variable }_{m, i t} * \text { Return }_{i t}+\sum \psi_{j, m} \text { Control variable }_{m, i t} * \text { Neg }_{i t} \\
& +\sum \delta_{j, m} \text { Control variable }_{m, i t} * \text { Return }_{i t} * \text { Neg }_{i t}+\varepsilon_{j, i t}
\end{aligned}
$$

where $j=0$ for the regime where firms incorporate out-of-state (i.e., HomeState $=0$ ), and $j=1$ for the regime where firms incorporate in their home state (i.e., HomeState $=1$ ).

In Equation (2), Earn is firm i's reported performance, Return is the firm's real performance, and $\mathrm{Neg}$ is a dummy variable equal to 1 for bad news $($ Return $<0$ ) and 0 otherwise. A higher value of the Basu coefficient on Return*Neg indicates higher conservatism. The test variable of interest is StateLawIndex*Return*Neg. Following Bebchuk and Cohen (2003), we construct StateLawIndex as the number of state antitakeover laws (i.e., control share statute, fair price statute, business combination statute, poison pill endorsement statute, and constituencies statute) in the state-year in which the firm is incorporated. As Bebchuk and Cohen (2003, p. 409) note, not only does the variety of takeover deterrents available to a firm increase with the number of antitakeover laws governing the firm, but an increasing number of

\footnotetext{
${ }^{14}$ An alternative approach is to create a dummy variable to differentiate between these two groups of firms and interact this variable with other variables. However, given that the basic Basu (1997) model per se includes a twoway interaction term (Return*Neg), combining the dummy variable with StateLawIndex and the Basu model would yield four-way interaction terms.
} 
antitakeover statutes also sends an "antitakeover message to state courts and to potential and existing incorporators" that the state would be likely to provide further takeover protection valuable for firms. ${ }^{15}$ Prior studies (e.g., Wald and Long, 2007; Qi and Wald, 2008; Francis et al., 2010; Mansi et al. 2010) have employed this index and its variants as proxies for the strength of the state-level takeover protection in recent studies. If we reject Hypothesis 1 in favor of the shareholder view (i.e., the shareholder demand view dominates the debtholder demand view), then the coefficient on StateLawIndex*Return*Neg will be positive. Conversely, if we reject Hypothesis 1 in favor of the debtholder view, then the coefficient will be negative.

Following prior accounting studies (e.g., Khan and Watts 2009), we include firm size ( $\log ($ FirmSize)), growth $(M / B)$, and leverage (Leverage) to control for the effects of contracts, litigation, taxation, and regulation on conservatism. In addition, we control for various measures of investment opportunities and investment cycle (i.e., $P P \& E \%, R \& D \%, D e p E x p \%$ and $A d v \operatorname{Exp} \%)$. We also control for the strength of firm-level governance as measured by institutional ownership (InstiOwn\%). We interact these variables with each of the elements of the Basu model. In addition, we add a set of state of location dummies and year dummies as well as the interactions between these dummies and the Basu elements to control for home state and year effects. Finally, we include a set of firm dummies as standalone terms to control for firm fixed effects. As Ball et al. (2013) suggest, this simple firm fixed effects regression essentially eliminates bias in the standard Basu regression estimator. ${ }^{16}$

\subsection{Sample selection and descriptive statistics}

\footnotetext{
${ }^{15}$ Following Wald and Long (2007), we further use the RiskMetrics database to adjust each firm's index value by the firm's opt-out decision.

${ }^{16}$ Ball et al. (2013) also note that the inclusion of commonly used variables for firm characteristics such as firm size, the market-to-book ratio, and leverage also helps reduce such bias in the Basu estimator.
} 
To correct for endogeneity bias resulting from firms self-selecting themselves into states with strong antitakeover statutes, we test the sample period $1987-2011$. We obtain the financial data and stock market data required by our variables from merging Compustat and CRSP databases. We retrieve institutional ownership data from the Thompson Financial database. The RiskMetrics database provides information on firms' historical state of incorporation and opt-out decisions. After merging these databases, we eliminate firm-years in which firms reincorporated, because these observations are not comparable with others.

Table 2, Panel A presents the highest number of state antitakeover statutes adopted by each state and the number of sample firms incorporated in each state. ${ }^{17}$ States differ substantially in their number of antitakeover statutes, with a maximum of five laws in nine states and the minimum of 0 in eight states. Such variance allows us to explore the effect of state-level takeover protection on conservatism.

Table 2, Panel B reports descriptive statistics after winsorizing all continuous variables at the top and bottom percentiles. Similar to prior studies (e.g., Wald and Long 2007), we find that the average firm has two antitakeover laws. This panel also reveals a number of interesting patterns after splitting the full sample into home-state and out-of-state subsamples. For example, an average firm in the home-state subsample is incorporated in a state with over three antitakeover statutes while a firm in the out-of-state subsample is incorporated in a state with about 1.32 state laws. In addition, firms in the out-of-state subsample are more geographically dispersed $($ mean $=2.070)$ and have lower home-state employment $($ mean $=0.0006)$ than those in the in-state subsample (mean $=1.922$ and 0.0008 , respectively).

\footnotetext{
${ }^{17}$ States generally passed their second-generation antitakeover statutes during the mid- to late-1980s. After 1991 when four states passed antitakeover statutes, no state enacted such statutes till the end of our sample period.
} 


\section{Empirical results}

\subsection{Baseline analyses}

Table 3 reports the results of the first-stage probit regression. The coefficient on Home StateLawIndex is positive and significant, consistent with Wald and Long (2007) and suggests that firms headquartered in states with more antitakeover laws are more likely to remain in their home state. Consistent with Bebchuk and Cohen's (2003), we also find that firms with larger sizes $(\log ($ FirmSize $))$ are less likely to incorporate in their home state. Also, we find that coefficients on financial leverage (Leverage), growth opportunities $(M / B)$, capital investments $(P P \& E \%)$, and investment cycle $(D e p E x p \%)$ are significant, suggesting that these economic factors are important determinants of firms' incorporation decision. We also find that firms with higher institutional ownership (InstiOwn\%) are less likely to incorporate in their home states.

Importantly, both instrumental variables are significantly associated with firms' incorporation decision. Firms with higher Home-state Employment or lower geographic dispersion (Log(OperatingStates) ) are more likely to incorporate in their home state, which is consistent with the predictions of Bebchuk and Cohen (2003) as well as intuitive. The incremental explanatory power of these two variables is also sizable. The first-stage regression has a partial- $\mathrm{R}^{2}$ of 0.02 on these two instruments, which alleviates possible concerns that our estimation suffers from bias due to weak instruments (Bound et al., 1995).

Table 4 presents the results of the conservatism analysis. To save space, we only report coefficients on the interactions between various determinants and Return*Neg. For ease of comparison, Column (1) reports the results of the full sample regression, Columns (2) and (3) report the results of the second-stage analysis that include such terms to account for the endogenous incorporation choice. Column (1) shows that the coefficient on 
StateLawIndex*Return*Neg is not significant, suggesting that ATLs have no impact on conservatism in the entire sample. Such result is also consistent with Wald and Long (2007) who do not find a significant effect of ATLs on another corporate outcome (financial leverage) in the full sample over the period since 1987. In addition, we find that firms with larger sizes, higher $M / B$ ratios, or lower financial leverage tend to have lower levels of conservatism, suggesting that the demand for conservatism is lower in these firms (Khan and Watts, 2009).

In Columns (2) and (3), we split the sample into home-state and out-of-state incorporation subsamples and correct for endogeneity bias by including the interactions of InvMills with the Basu elements (Return, Neg, and Return*Neg). In the subsample where firms are incorporated in their home states, the coefficient on StateLawIndex*Return*Neg is positive but not significant. By comparison, in the subsample where firms are incorporated out-of-state, the coefficient on StateLawIndex*Return*Neg is negative and significant, suggesting that firms subject to more ATLs tend to have lower conservatism.

The results are consistent with the prediction of the debtholder demand view. Specifically, as stronger ATLs align shareholder and debtholder interests better and thus lower agency costs of debt, debtholder demand for conservatism declines accordingly. Because conservatism per se is a tool potentially costly to managers and shareholders, firms (and their management) are more likely to adopt lower conservatism in the presence of stronger ATLs. This decreasing effect is more pronounced in out-of-state incorporated firms, because unlike the incumbent managers of home-state firms who are more likely to benefit from local favoritism, those of out-of-state incorporated firms are less likely to receive such favorable treatment with respect to ATLs-related issues (e.g., Bebchuk and Cohen, 2003). Accordingly, to the extent that managers of out-of-state firms are less entrenched by ATLs, the potential downside of ATLs is 
likely to be less harmful to shareholders of out-of-state firms. Therefore, shareholder demand for conservatism to address ATLs-associated agency problems is relatively weaker for out-of-state firms than for home-state firms. In sum, out-of-state firms (and their management), when subject to stronger ATLs, appear to adopt lower conservatism without facing significant resistance by shareholders.

\subsection{Robustness checks}

We perform a battery of robustness checks in this section. First, we adopt three alternative measures of the ATL index. StateLawIndex with Recap is the antitakeover index measured as the number of state antitakeover laws included in StateLawIndex as well as the recapture statute in the state-year in which the firm is incorporated (Qi and Wald, 2008; Mansi et al., 2010). ThreeLawIndex is measured as the number of three major antitakeover laws (i.e., control share statute, fair price statute, and business combination statute). Some prior studies (e.g., Cheng et al., 2005) focus on these three state laws. BCLaw is a dummy variable with a value of 1 if the state has a BC law in place and 0 otherwise. In Table 4, Columns (4), (6), and (8) present the home-state regression results using these three measures, respectively, and Columns (5), (7), and (9) report the corresponding out-of-state results. The main results on the effect of ATLs on conservatism are consistent with the findings documented based on the baseline analyses.

Second, we also use an alternate sample period $1982-2011$. ATLs may have become an important determinant of firms' incorporation decisions as early as when the first secondgeneration state ATL, a CSA law, was adopted in Ohio in 1982, although the constitutionality of the law was yet to be resolved. Hence, we select the year 1982 as an alternate starting point. As Columns (1) and (2) of Table 5 show, the results for this longer period remain essentially 
unchanged. Indeed, the magnitude of the coefficient on Return*Neg*StateLawIndex for the outof-state subsample is smaller than that of the corresponding, post-constitutionality coefficient in Table 4, suggesting that the constitutionality of ATLs enhances the impact of such laws on accounting conservatism.

Third, we control for additional variables. Approximately $57 \%$ of our sample firms are incorporated in Delaware. To ensure that our baseline results are not driven by the ATLs in Delaware, we create a dummy variable Delaware with a value of 1 for firms incorporated in Delaware and 0 otherwise, and interact Delaware with the Basu elements. Columns (3) and (4) report the results after controlling for these terms. Similar to our baseline results, the coefficient on Return*Neg*StateLawIndex remains significant and negative in the out-of-state subsample, but not significant in the in-state subsample. In Columns (5) and (6) of Table 5, we control for the effects of firm-level antitakeover provisions on conservatism by interacting Bebchuk et al's (2009) entrenchment index with the Basu elements. Our main results remain unchanged.

Fourth, we adopt two alternative measures of conservatism. Instead of using buy-andhold return as a proxy for firms' real performance, we use buy-and-hold abnormal return (BHAR) as robustness check. BHAR is measured by compounded monthly stock returns for the twelvemonth period of the fiscal year, minus compounded monthly value-weighted CRSP market returns for the same period. As shown in Columns (7) and (8) of Table 5, our results remain unchanged.

We also adopt a measure of conservatism based on the reversion tendency of earnings. According to Basu (1997) and Ball and Shivakumar (2005), if bad news is recognized much more quickly than good news, the negative earnings changes will be less persistent and will tend to reverse more quickly than positive earnings changes. This asymmetric reversal of earnings 
changes model (equation (3) below) avoids the risk of incorrect inferences arising from market inefficiencies.

$$
\operatorname{EarnCh}=\beta_{0}+\beta_{1} \mathrm{Neg}+\beta_{2} \operatorname{Lag}(\operatorname{EarnCh})+\beta_{3} \operatorname{Lag}(\operatorname{EarnCh}) * N e g+\varepsilon
$$

Where EarnCh is change in net income before extraordinary items between year $t-1$ and year $t$, deflated by the beginning-of-the-period market value of common equity; Lag (EarnCh) is EarnCh in the previous year (i.e., earnings changes between year t-2 and year t-1); Neg is a dummy variable coded as 1 if $\operatorname{Lag}$ (EarnCh) is negative, 0 otherwise. $\beta_{3}$ measures the incremental reversal (or persistence) of negative income changes, relative to positive income changes, which captures the degree of conditional conservatism in financial reporting (Basu, 1997; Ball and Shivakumar, 2005). A negative estimate of this coefficient suggests a greater reversal (or a decreased persistence) of negative income changes than that of positive income changes. Thus, a more negative value of $\beta_{3}$ indicates higher conservative reporting.

Columns (9) and (10) of Table 5 present the second stage results using EarnCh as a proxy for conservatism. Consistent with the results in Tables 4, we find a significant and negative association between conservatism and ATLs in the out-of-state subsample. Taken together, these results provide strong evidence consistent with the debtholder demand view.

\section{Controlling for time trend in difference-in-differences design}

\subsection{Importance of controlling for time trend}

A large number of prior studies (e.g., Bertrand and Mullainathan, 1999, 2003; Cheng et al., 2005) have used the setting of the introduction of state antitakeover laws during the mid- to late-1980s to test the effects of takeover protection on various corporate outcomes. A key feature of this setting is that state ATLs only affect firms incorporated in the state that enacted the laws. 
If economy-wide shocks (e.g., a recession) affect both firms incorporated in the enacting states (i.e., treatment firms) and firms incorporated in other states (i.e., control firms) in the same way, researchers can adopt a DiD methodology (i.e., compare pre-post differences in outcome variables of treatment firms versus those differences of control firms) and thus obtain a purified measure of the law's effect.

In the ATL setting, however, many states passed ATLs at different times. To accommodate this staggered nature of the laws, prior studies (e.g., Bertrand and Mullainathan, 1999 and 2003; Cheng et al., 2005) normally adopt the following regression model to implement the DiD methodology:

$$
\text { DepVar }_{i t}=\alpha_{t}+\beta_{i}+\delta \text { Law }_{i}{ }^{*} \text { After }_{i t}+\lambda \text { Control variables }_{i t}+\varepsilon_{i t}
$$

In this model, After $i t$ is a firm-year specific dummy variable for firm years after the passage of the law, and $L a w_{i}$ is a dummy variable with a value of 1 for firms incorporated in a state passing a law, and 0 otherwise. $\beta_{i}$ is a set of state of incorporation dummies that directly controls for state fixed effects. $\alpha_{t}$ refers to a set of year dummies that controls for economy-wide shocks. One advantage of including these year dummies is that it "takes all firms incorporated in states not passing a law at time $t$ as the control group for a law passed at time $t$, even if they have already passed one or will pass one later" (Bertrand and Mullainathan, 1999, p. 544). After controlling for concurrent economy-wide shocks, $\delta$ captures the purified, DiD effect of ATLs.

A recent study by Jayaraman and Shivakumar (2013) finds that firms with high contracting pressures experience an increase in conservatism after the passage of state antitakeover laws. They gauge conservatism by the following Basu (1997) measure:

$$
\operatorname{Earn}_{i t}=\beta_{0}+\beta_{1} * \text { Return }_{i t}+\beta_{2} * N_{e g} g_{i t}+\beta_{3} * \operatorname{Return}_{i t} * \mathrm{Neg}_{i t}+\varepsilon_{i t}
$$


They interpret the findings as evidence that heightened agency costs of debt, which is attributed to the passage of ATLs, increases the demand for accounting conservatism. However, a drawback in their model used for comparing treatment firms versus control firms (i.e., Model (3) in JS) is that they include only year fixed effects in the augmented Basu model, where the dependent variable is not conservatism but earnings (Earn). ${ }^{18}$ This model specification indeed controls for the effect of contemporaneous economy-wide shocks on earnings rather than on conservatism. As a result, the control group in their Model (3) comprises "firms in states that did not pass antitakeover laws during the sample period" (Jayaraman and Shivakumar, 2013, p. 104). Because there are only a small number of firms in such states, this control group departs substantially from the control group in the foregoing DiD equation (Model (1)) that allows for the staggering of ATLs.

The omission of controlling for time trends unrelated to ATLs is likely to cause a serious problem to a study that examines the effect of ATLs on conservatism. As Figure 3 of Basu (1997) shows, there is an aggregate upward trend in accounting conservatism during the period 1982 - 1990. Likewise, Table 5 of Givoly and Hayn (2000) reports that the value of the Basu coefficient increases steadily from 0.292 in the subperiod $1976-1980$ to 0.521 in the last subperiod, 1991 - 1998. Figure 2 of Givoly and Hayn (2000) also demonstrates a similar trend towards a greater level of earnings skewness, another indicator of accounting conservatism. They note that, "it has become increasingly negatively skewed over time... with the increase in skewness occurring in the mid- to late 1970s and accelerating in the 1980s" (Givoly and Hayn, 2000, p. 310). Basu (1997) attributes such an economy-wide increase in conservatism to an

${ }^{18}$ In describing their model that focuses only on treatment firms (Model (2) in Section 3.1.1), Jayaraman and Shivakumar (2013) note that interacting the Basu coefficient with the year indicators do not affect their results. However, it remains unclear whether this modified specification affects the results of their tests that compares treatment firms versus control firms (i.e., Model (3) in Section 3.1.2), where a difference-in-differences design is needed. 
increase in "auditor legal liability exposure" during this period. Therefore, in the absence of controlling for secular changes in conservatism over time, the estimated coefficient on state ATLs would likely contain a bias that accounts for the statistical association between state ATLs and conservatism.

\subsection{Variable measurement, sample selection, and results}

To confirm this notion, we replicate Table 7 of Jayaraman and Shivakumar (2013), the first table that not only compares treatment firms versus control firms, but also controls for various determinants of conservatism including firm size (Log(FirmSize)), market-to-book $(M / B)$, and the inverse of stock price (PrcInv). As in JS (2013), we select the sample period from 1976 to 1995 , which covers both pre- and post-passage periods. We obtain financial data and stock market data from merging Compustat and Center for Research on Security Prices (CRSP) databases. As shown in Table 1, we define our variables exactly the same as those in JS (Section 3.2. on p. 105). In addition, following JS, we focus on business combination (BC) laws. ${ }^{19}$ Accordingly, we create a dummy variable, AfterLaw, which equals 1 for treatment firms in the

years after the year of passage of the corresponding state's BC law, and 0 otherwise. ${ }^{20}$ It is set to 0 for other observations.

Consistent with their Table 7, we focus on firms with high contracting pressures, defined as those with increases in total debt (i.e., the sum of long-term debt (DLTT) and short-term debt (DLC)) between the pre- and post-passage periods. This requires sample firms to have at least one observation in both the pre-passage and post-passage periods (JS, p. 105). In addition, we

\footnotetext{
${ }^{19}$ JS's data on the passage years of state ATLs (Table 1, p. 107) are from Bertrand and Mullainathan (2003, p. 1048). This indicates that JS focuses on business combination laws.

${ }^{20}$ The "Afterlaw" variable is equivalent to the interaction term Law $_{i}{ }^{*}$ After ${ }_{i t}$ in Model (4).
} 
exclude observations in the year when the laws are passed. Finally, to mitigate the influence of outliers, we truncate Earn (deflated earnings) and Return (stock returns) at the top and bottom percentiles.

Table 6, Panel A reports descriptive statistics for variables used in the DiD tests after further winsorizing those control variables (i.e., $\log ($ FirmSize), $M / B$, and PrcInv) at the top and bottom percentiles. ${ }^{21}$ Our sample consists of 32,856 firm-years. ${ }^{22}$ The descriptive statistics are generally comparable with those reported in prior studies (e.g., Jayaraman and Shivakumar, 2013; Beatty et al., 2008). For example, the mean value of the mean buy-and-hold annual returns (Return) is 0.179 and the mean $M / B$ ratio of the sample firms is 1.990 .

We first verify the existence of the upward trend in conservatism in our sample by estimating the Basu model (Equation (5)) by year. The annual slope coefficients $\beta_{3}$ on Return $_{i t}{ }^{*}$ Neg over the period 1976 - 1995 are plotted in Figure 1. As can be seen, there is an overall upward, though bumpy, trend in accounting conservatism from early 1980s to 1995, the same period in which state antitakeover laws were passed. To further verify the existence of this trend, we follow Givoly and Hayn (2000) and estimate the Basu model over five-year intervals: 1976 - 1980, 1981 - 1985, 1986 - 1990, and 1991 - 1995. We report the Basu coefficients on Return*Neg in Table 6, Panel B. Over the recent three sub-periods, there is an upward trend in conservatism (from 0.200 in the sub-period 1981 - 1985, to 0.257 in the sub-period 1986 - 1990, and to 0.316 in the last sub-period 1991 - 1995). This upward trend is consistent with that

\footnotetext{
${ }^{21}$ JS does not explicitly disclose whether they winsorize these continuous control variables, a common practice in prior studies. However, the descriptive statistics in their Table 2 suggests that they winsorize these variables. For example, the unwinsorized $M / B$ has a maximum of 2036.624. By comparison, in their Table $2, M / B$ has a maximum of 25.329 .

${ }^{22}$ Our sample size is larger than that of JS as reported in Table 7 of their paper (27,761 firm-years). It remains unclear whether JS excludes financial services firms $(6000-6500)$ and utilities firms $(4400-5000)$ from their sample. After excluding these firms, our sample contains 26,033 firm-years. The replication based on this sample exhibits the same pattern as that in Table 3.
} 
reported in Table 5 of Givoly and Hayn (2000). ${ }^{23}$ Thus, it is critically important to control for the economy-wide effect for all firms in the sample.

Table 7 presents the regression results using the Basu (1997) measure as the proxy for accounting conservatism. As in JS, we use robust standard errors clustered by state of incorporation. Columns (1) through (4) include year and state of incorporation fixed effects, while Columns (5) through (8) replace state fixed effects with firm fixed effects to control for cross-sectional differences in expected earnings and thus eliminate the related bias in standard Basu (1997) estimates (Ball et al., 2013). The estimated coefficient on the interaction term Return*Neg*Afterlaw captures the impact of ATLs on conservatism.

Columns (1) and (5) replicate Table 7 of JS (2013) where year dummies are not interacted with the elements of the Basu model. Consistent with JS (2013), the coefficient on Return*Neg*Afterlaw is positive and significant, suggesting an increase in conservatism after the passage of antitakeover laws. In particular, the coefficient in Column (1) of our Table 7 is very close to that in Column (1) of JS' Table 7 in magnitude (0.052 versus 0.055$){ }^{24}$

In Columns (2) and (6), we interact year dummies with the key element of the Basu model, Return*Neg. During our 20-year sample period, we choose year 1988 as the benchmark year and create 19 dummy variables to indicate the other 19 years. In 1988, Delaware (the state

\footnotetext{
${ }^{23}$ There is a key difference between our sample and that of Givoly and Hayn (2000). Givoly and Hayn (2010) use a constant sample of 896 firms that exists for the period from 1968 to 1998. These firms are mainly large and successful firms, which may suggest a survivor bias problem in the study. Our study instead replicates Jayaraman and Shivakumar (2013, JS) and uses a sample of all firm-years with non-missing data over the period 1976 - 1995. Therefore, the trend shown in Givoly and Hayn (2000) may not exactly be generalized to a broader sample.

${ }^{24}$ The coefficient on Return*Neg*Afterlaw in our Table 7, Column (5) (a firm fixed effects specification), 0.037, is smaller than the corresponding coefficient (0.057) in JS's table. As footnote 19 discusses, our sample size is somewhat larger than that of JS (it is unclear whether JS excluded financial services and utilities industries), which may account for the difference in the magnitude of these two coefficients. In addition, our Table 7, Column (5) coefficient is also smaller than the corresponding coefficient in our Table 7, Column (1). As Ball et al. (2013) note, the inclusion of firm fixed effects in the Basu model helps address the bias caused by correlated omitted variables. Thus, a firm fixed effects model specification would yield a less biased estimate of the effect of ATLs on conservatism.
} 
where more than $50 \%$ of US firms are incorporated) and 7 other states (i.e., Georgia, Idaho, Maine, Nebraska, South Carolina, Tennessee, and Virginia) adopted BC laws. Therefore, the coefficient on AfterLaw*Return*Neg captures, to a large extent, the effect of BC laws adopted in 1988 on conservatism. The interactions between year dummies and Return*Neg (e.g., yearcdum $1989 *$ Return $* N e g$ ) control for the effects of economy-wide trends in non-1988 years relative to 1988. As Columns (2) and (6) show, the coefficient on Return*Neg*Afterlaw becomes insignificant and its magnitude drops substantially after controlling for these interactions. In addition, while most of the coefficients in the prior-1988 period are not significant, the coefficients on the post-1988 interaction terms are generally both positive and significant, indicating that conservatism in these later years is higher than in $1988 .{ }^{25}$ This economy-wide trend in conservatism is also consistent with prior studies. For example, Figure 3 of Basu (1997) shows that conservatism in 1990 (the last year in his sample period) is significantly higher than that in 1988, and Figure 2 of Givoly and Hayn (2000) also shows that conservatism increased steadily from late-1980s to mid-1990s.

In Columns (3) and (7), we further interact year dummies with all the three elements of the Basu model (i.e., Return, Neg, and Return*Neg). Again, when these interaction terms are included, the relation between Return*Neg*Afterlaw and accounting conservatism disappears. Finally, to mitigate concerns that including the large number of control variables (e.g., interactions) may result in unreliable inferences, we adopt a simplified model. Specifically, we follow Lawrence, Sloan, and Sun (2013) and include beginning of period $M / B$ and its interactions with the Basu elements to control for non-discretionary conservatism. As reported in

\footnotetext{
${ }^{25}$ These coefficients are also jointly significant. For example, the F-value of these coefficients is $260.218(p<0.01)$ for the regression in Column (2).
} 
Columns (4) and (8), after controlling for economy-wide trends in conservatism, there is no significant association between ATLs and conservatism.

Overall, our findings suggest that the positive association between ATLs and conservatism, as documented in Jayaraman and Shivakumar (2013), is likely to be contaminated by the economy-wide trend in conservatism during our sample period.

\section{Summary and conclusion}

This study examines the effect of second-generation state ATLs on accounting conservatism. Using a novel methodology and focusing on a more recent sample period, we document a negative association between ATLs and conservatism. Specifically, after splitting our sample into in-state and out-of-state incorporated firms and correcting for the self-selection bias due to different firms sorting themselves by incorporating in different states, we find that more ATLs are associated with lower conservatism in the out-of-state subsample. We interpret this finding as evidence for the debt-holder demand view. These findings are more consistent with ATLs serving as a substitute for conservatism in mitigating agency conflicts between debtholders and shareholders. In addition, it adds to the growing empirical evidence that corporate governance mechanisms can have divergent effects on different stakeholders of the firm.

\section{Acknowledgements}

We thank Larry Gordon (editor-in-chief), Marty Loeb (editor), and two anonymous referees for their helpful suggestions and comments. Shijun Cheng's research has been supported by the National Science Foundation of China Key Project \# 71232005, and the Robert H. Smith School of Business, University of Maryland. Augustine Duru and Yijiang Zhao gratefully acknowledge the financial support provided by the Kogod Research Grant at American University. 


\section{References}

Adut, D., Holder, A. D., Robin, A., 2013. Predictive versus opportunistic earnings management, executive compensation, and firm performance. J. Account. Public Policy 32 (3), 126-146.

Ahmed, A., Duellman, S., 2007. Accounting conservatism and board of director characteristics: an empirical analysis. J. Account. Econ. 43, 411-437.

Ahmed, A., Billings, B., Morton, R., Stanford, M., 2002. The role of accounting conservatism in mitigating bondholder - shareholder conflicts over dividend policy and in reducing debt costs. Account. Rev. 77, 867-890.

Anderson, R. C., Mansi, S.A., Reeb, D.M., 2003. Founding family ownership and the agency cost of debt. J. of Financ. Econ. 68, 263-285.

Anderson, R. C., Reeb, D. M., 2003. Founding-family ownership and firm performance: evidence from the S\&P 500. J. Finance 58, 1301-1328.

Anderson, R. C., Mansi, S. A., Reeb, D. M., 2004. Board characteristics, accounting report integrity, and the cost of debt. J. Account. Econ. 37 (3), 315-342.

Armstrong, C.S., Balakrishnan, K., Cohen, D., 2012. Corporate governance and the information environment: evidence from state antitakeover laws. J. Account. Econ. 53, 185-204.

Ashbaugh-Skaife, H., Collins, D. W., LaFond, R., 2006. The effects of corporate governance on firms' credit ratings. J. Account. Econ. 42 (1), 203-243.

Ball, R., 2001. Infrastructure requirements for an economically efficient system of public financial reporting and disclosure. Brookings-Wharton Papers on Financial Services 127-169.

Ball, R., Bushman, R., Vasvari, F., 2008a. The debt-contracting value of accounting information and loan syndicate structure. J. Account. Res. 46, 247-287.

Ball, R., Kothari, S. P., Nikolaev, V. V., 2013. On estimating conditional conservatism. Account. Rev. 88 (3), 755-787.

Ball, R., Robin, A., Sadka, G., 2008b. Is financial reporting shaped by equity markets or by debt markets? An international study of timeliness and conservatism. Rev. Acc. Stud. 13 (2), 168-205.

Ball, R., Shivakumar, L., 2005. Earnings quality in U.K. private firms. J. Account. Econ. 39, 83-128.

Basu, S., 1997. The conservatism principle and asymmetric timeliness of earnings. J. Account. Econ. 24, 3-37.

Beatty, A., Weber, J., Yu, J., 2008. Conservatism and debt. J. Account. Econ. 45 (2-3), 154-175.

Bebchuk, L. A., 1992. Federalism and the corporation: the desirable limits on state competition in corporate law. Harvard Law Review 105, 1435-1510.

Bebchuk, L., Cohen, A., 2003. Firms' decisions where to incorporate. Journal of Law and Economics 46 (2), 383-425.

Bebchuk, L., Cohen, A., Ferrell, A., 2009. What matters in corporate governance? Rev. Financ.

Stud. 22, 783-827.

Berger, P. G., Ofek, E., Yermack, D. L., 1997. Managerial entrenchment and capital structure decisions. The J. Finance 52, 1411-1438.

Bertrand, M., Mullainathan, S., 1999. Is there discretion in wage setting? Rand Journal of Economics 30, $535-554$.

Bertrand, M., Mullainathan, S., 2003. Enjoying the quite life? Managerial behavior following antitakeover legislation. J. Polit. Econ. 111, 1042-1075.

Bound, J., Jaeger, D., Baker, R., 1995. Problems with instrumental variables estimation when the correlation between the instruments and the endogenous explanatory variable is weak. Journal of the American Statistical Association 90, 443 - 450.

Brown, N. C., Pott, C., Wömpener, A., 2014. The effect of internal control and risk management regulation on earnings quality: evidence from Germany. J. Account. Public Policy 33 (1), 1-31.

Bushman, R., Piotroski, J., 2006. Financial reporting incentives for conservative accounting: the influence of legal and political institutions. J. Account. Econ. 42, 107-148.

Byard, D., Li Y., Weintrop, J., 2006. Corporate governance and the quality of financial analysts' 
information. J. Account. Public Policy 25 (5), 609-625.

Chava, S., Livdan, D., Purnanandam, A., 2008. Do shareholder rights affect the cost of bank loans? Rev. Financ. Stud. 22 (8), 2973-3004.

Chen, K., Elder, R., Hung, S., 2014. Do post-restatement firms care about financial credibility? Evidence from the pre- and post-SOX eras. J. Account. Public Policy 33, 107-126.

Chen, J., Lobo, G., Wang, Y., Yu, L., 2013. Loan collateral and financial reporting conservatism: Chinese evidence. Journal of Banking and Finance 37, 4989-5006.

Cheng, S., Indjejikian, R., 2009. The market for corporate control and CEO compensation: complements or substitutes. Contemp. Account. Res. 26 (3), 701-728.

Cheng, S., Nagar, V., Rajan, M., 2005. Identifying control motives in managerial ownership: evidence from antitakeover regulation. Rev. Financ. Stud. 18 (2), 637-672.

Clatworthy, M., Peel, M., 2013. The impact of voluntary audit and governance characteristics on accounting errors in private companies. J. Account. Public Policy 32 (3), 1-25.

Cremers, M., Nair, V.B., Wei, C., 2007. Governance mechanisms and bond prices. Rev. Financ. Stud. 20 (5), 1359-1388.

Doukakis, L., 2014. The effect of mandatory IFRS adoption on real and accrual-based earnings management activities. J. Account. Public Policy 36 (6), 551-572.

Faleye, O., 2007. Classified boards, firm value, and managerial entrenchment. J. Financ. Econ. 83, 501529.

Francis, B., Hasan, I., Kose, J., Waisman, M., 2010. The effect of state antitakeover laws on the firm's bondholders. J. Financ. Econ. 96 (1), 127-154.

Francis, J., Martin, X., 2010. Acquisition profitability and timely loss recognition. J. Account. Econ. 49, $161-178$

Lara, J.M.G., Osama, B.G., Penalva, F., 2009. Accounting conservatism and corporate governance. Rev. Acc. Stud. 14, 161-201.

Lara, J.M.G., Osama, B.G., Penalva, F., 2016. Conditional conservatism and firm investment efficiency. J. Account. Econ. 61, 221-238.

Garcia, D., Norli, O., 2012. Geographic dispersion and stock returns. J. Financ. Econ. 106 (3), 547-565.

Garvey, G., Hanka, G., 1999. Capital structure and corporate control: the effect of antitakeover statues on firm leverage. J. Finance 54, 519-546.

Givoly, D., Hayn, C., 2000. The changing time-series properties of earnings, cash flows and accruals: has financial reporting become more conservative? J. Account. Econ. 29, 287-320.

Gompers, P.A., Ishii, J.L., Metrick, A., 2003. Corporate governance and equity prices. The Quarterly Journal of Economics 118, 7-55.

Hansen, B., Pownall, G., Prakash, R., Vulcheva, M., 2014. Earnings changes associated with relaxing the reconciliation requirement in non-U.S. firms' SEC filings. J. Account. Public Policy 33 (5), 424-448.

Heckman, J., 1979. Sample selection bias as a specification error. Econometrica 47 (1), 153-161.

Jayaraman, S., Shivakumar, L., 2013. Agency-based demand for conservatism: evidence from state adoption of antitakeover laws. Rev. Acc. Stud. 18 (1), 95-134.

Jeanjean, T., Stolowy, H., 2008. Do accounting standards matter? An exploratory analysis of earnings management before and after IFRS adoption. J. Account. Public Policy 27 (6), 480-494.

Jenkins, D., Velury, U., 2008. Does auditor tenure influence the reporting of conservative earnings? J. Account. Public Policy 27, 115-132.

Kalelkar, S. R., Nwaeze E. T., 2011. Sarbanes-Oxley Act and the quality of earnings and accruals: market-based evidence. J. Account. Public Policy 30 (3), 275-294.

Karpoff, J., Malatesta, P., 1989. The wealth effects of second-generation state takeover legislation. J. Financ. Econ. 25, 291-322.

Khan, M., Watts, R.L., 2009. Estimation and empirical properties of a firm-year measure of accounting conservatism. J. Account. Econ. 48, 132-150.

Kim, B., Pevzner, M., 2010. Conditional accounting conservatism and future negative surprises: an empirical investigation. J. Account. Public Policy 29, 311-329. 
Klock, M., Maxwell, W., Mansi, S., 2005. Does corporate governance matter to bondholders? Journal of Financial and Quantitative Analysis 40, 693-719.

Koh, P., 2007. Institutional investor type, earnings management and benchmark beaters. J. Account. Public Policy 26, 267-299.

LaFond, R., Roychowdhury, S., 2008. Managerial ownership and accounting conservatism. J. Account. Res. 46, 101-135.

LaFond, R., Watts, R.L., 2008. The information role of conservative financial statements. Account. Rev. $83(2), 443-478$.

Lawrence, A., Sloan, R., Sun, Y., 2013. Non-discretionary conservatism: evidence and implications. J. Account. Econ. 56 (2), 112-133.

Li, D., 2010. Does auditor tenure affect accounting conservatism? Further evidence. J. Account. Public Policy 29, 226-241.

Maddala, G., 1986. Limited-Dependent and Qualitative Variables in Econometrics. Cambridge University Press, Cambridge.

Mansi, S., Maxwell, W., Wald, J., 2010. Creditor protection laws and the cost of debt. Journal of Law and Economics 52, 701-726.

Masulis, W., Wang, C., Xie, F., 2007. Corporate governance and acquirer returns. J. Finance 39, 18511889.

Nikolaev, V., 2010. Debt covenants and accounting conservatism. J. Account. Res. 48, 137-175.

Qi, Y., Wald, J., 2008. State laws and debt covenants. Journal of Law and Economics 51 (1),179-207.

Qiu, J., Yu, F., 2009. The market for corporate control and the cost of debt. J. Financ. Econ. 93, 505-524.

Rauh, J., 2006. Investment and financing constraints: evidence from the funding of corporate pension plans. J. Finance 61, 33-71.

Romano, R., 1987. The state competition debate in corporate law. Cardozo Law Review 8, 709-757.

Roychowdhury, S., 2010. Discussion of "Acquisition profitability and timely loss recognition" by Francis, J., and Martin, X. J. Account. Econ. 49, 179-183.

Wald, J.K., Long, M.S., 2007. The effect of state laws on capital structure. J. Financ. Econ. 83, 297-319.

Sunder, S., 2016. Better financial reporting: meanings and means. J. Account. Public Policy 35, 211-223.

Wang, M., Hussainey, K., 2013. Voluntary forward-looking statements driven by corporate governance and their value relevance. J. Account. Public Policy 32 (3), 26-49.

Watts, R., 2003. Conservatism in accounting, Part I: explanations and implications. Account. Horizons $17,207-221$.

Zhang, J., 2008. The contracting benefits of accounting conservatism to lenders and borrowers. J. Account. Econ. 45, 27-54.

Zhao, Y., Allen, A., Hasan, I., 2013. State antitakeover laws and voluntary disclosure. Journal of Financial and Quantitative Analysis 48 (2), 637-668.

Zhao, Y., Chen, K., 2009. Earnings quality effect of state antitakeover statutes. J. Account. Public Policy $28(2), 92-117$.

Zhao, Y., Chen, K., Zhang, Y., Davis, M., 2012. Takeover protection and managerial myopia: evidence from real earnings management. J. Account. Public Policy 31, 109-135. 
Table 1

Variable definitions. ${ }^{*}$

Return = firm $i$ 's annual buy-and-hold return measured in year $\mathrm{t}$;

Neg = a dummy variable with a value of one if Return $<0$, and zero otherwise;

FinPerf = firm i's earnings before extraordinary items per share (IB) deflated by market value of equity (share price (PRCC_F) times common shares outstanding (CSHO) at the beginning of the fiscal year $\mathrm{t}$;

$\log$ (FirmSize $)=$ the natural $\log$ of market value of equity at the beginning of the fiscal year $\mathrm{t}$;

Leverage $=$ the ratio of total debt (DLTT + DLC) to total assets (AT) at the beginning of fiscal year t;

$M / B=$ the ratio of the market value of equity to the book value of equity (CEQ) at the beginning of fiscal year t;

PrcInv $=$ the inverse of stock price (CRSP data item PRC) at the beginning of fiscal year $\mathrm{t}$ (Patatoukas and Thomas, 2011);

EarnCh $=$ change in net income before extraordinary items (IB) between year $t-1$ and year $t$, deflated by total assets (AT) at the beginning of the year $\mathrm{t}-1$;

$\operatorname{Lag}(E a r n C h)=$ EarnCh in the previous year (i.e., earnings changes between year t-2 and year t-1);

StateLawIndex $=$ the antitakeover index in year $\mathrm{t}$ measured as the number of state antitakeover laws (i.e., control share statute, fair price statute, business combination statute, poison pill endorsement statute, and constituencies statute,) in the state where the firm is incorporated;

TAconstraint $=$ a dummy equal to 1 if there is a total asset constraint in the state where the firm is incorporated, and 0 otherwise;

InstiOwn $\%=$ the percentage of ownership by institutional investors at the end of year $\mathrm{t}-1$;

$R D \%=$ the ratio of $\mathrm{R} \& \mathrm{D}$ expenditures (XRD) to total assets (AT) in year $\mathrm{t}-1 ;$

$A d v E x p \%=$ the ratio of firm i's advertising expenses (XAD) to total assets (AT) in year $t-1$;

$P P \& E \%=$ the ratio of firm i's net property, plant and equipment (PPENT) to total assets (AT) in year $t$ - 1 ;

DepExp\% = the ratio of firm i's depreciation expenses (DP) to total assets (AT) in year $t-1$;

HomeState $=$ a dummy variable with a value of 1 if the firm's home state (i.e., the state where the firm is headquartered) equals its state of incorporation, and 0 otherwise;

$\log$ (OperatingStates) $=$ the natural $\log$ of the number of U.S. states mentioned in the firm's Form 10-K filed with the SEC in year $t-1$

Home-state Employment $=$ the ratio of firm i's home state employees (i.e., total employees divided by the number of operating states) to the population of that state in year t-1;

InvMills $_{1}\left(\right.$ InvMills $\left._{0}\right)=$ the inverse Mills ratio calculated from the probit regression for the subset with the dependent variable equal to $1(0) ;$ Delaware $=$ a dummy equal to 1 if the firm is incorporated in Delaware and 0 otherwise;

BCFIndex $=$ the entrenchment index of firm $\mathrm{i}$ in year $\mathrm{t}$ that covers six firm-level antitakeover provisions (i.e., staggered boards, limits to shareholder bylaw amendments, limits to shareholder charter amendments, supermajority requirements for mergers, poison pills, and golden parachutes); 
Table 2

Panel A. Number of firms by state of incorporation and number of antitakeover laws.

\begin{tabular}{|c|c|c|c|}
\hline State of incorporation & Number of statutes & Number of firms & Percent \\
\hline Alabama & 0 & 4 & $0.135 \%$ \\
\hline Alaska & 0 & 3 & $0.101 \%$ \\
\hline Arizona & 4 & 7 & $0.236 \%$ \\
\hline Arkansas & 0 & 1 & $0.034 \%$ \\
\hline California & 0 & 88 & $2.966 \%$ \\
\hline Colorado & 1 & 9 & $0.303 \%$ \\
\hline Connecticut & 3 & 16 & $0.539 \%$ \\
\hline Delaware & 1 & 1825 & $61.510 \%$ \\
\hline District of Columbia & 0 & 2 & $0.067 \%$ \\
\hline Florida & 4 & 42 & $1.416 \%$ \\
\hline Georgia & 4 & 37 & $1.247 \%$ \\
\hline Hawaii & 3 & 3 & $0.101 \%$ \\
\hline Idaho & 5 & 3 & $0.101 \%$ \\
\hline Illinois & 4 & 17 & $0.573 \%$ \\
\hline Indiana & 5 & 34 & $1.146 \%$ \\
\hline Iowa & 3 & 11 & $0.371 \%$ \\
\hline Kansas & 2 & 8 & $0.270 \%$ \\
\hline Kentucky & 4 & 5 & $0.169 \%$ \\
\hline Louisiana & 3 & 9 & $0.303 \%$ \\
\hline Maine & 1 & 6 & $0.202 \%$ \\
\hline Maryland & 5 & 45 & $1.517 \%$ \\
\hline Massachusetts & 4 & 64 & $2.157 \%$ \\
\hline Michigan & 3 & 31 & $1.045 \%$ \\
\hline Minnesota & 4 & 46 & $1.550 \%$ \\
\hline Mississippi & 3 & 11 & $0.371 \%$ \\
\hline Missouri & 4 & 18 & $0.607 \%$ \\
\hline Montana & 0 & 1 & $0.034 \%$ \\
\hline Nebraska & 2 & 4 & $0.135 \%$ \\
\hline Nevada & 5 & 40 & $1.348 \%$ \\
\hline New Hampshire & 0 & 3 & $0.101 \%$ \\
\hline New Jersey & 4 & 51 & $1.719 \%$ \\
\hline New Mexico & 1 & 3 & $0.101 \%$ \\
\hline New York & 4 & 97 & $3.269 \%$ \\
\hline North Carolina & 3 & 29 & $0.977 \%$ \\
\hline Ohio & 5 & 69 & $2.326 \%$ \\
\hline Oklahoma & 2 & 9 & $0.303 \%$ \\
\hline Oregon & 4 & 22 & $0.741 \%$ \\
\hline Pennsylvania & 5 & 79 & $2.663 \%$ \\
\hline Rhode Island & 4 & 3 & $0.101 \%$ \\
\hline South Carolina & 3 & 10 & $0.337 \%$ \\
\hline South Dakota & 5 & 2 & $0.067 \%$ \\
\hline Tennessee & 5 & 27 & $0.910 \%$ \\
\hline Texas & 1 & 50 & $1.685 \%$ \\
\hline Utah & 2 & 11 & $0.371 \%$ \\
\hline Vermont & 1 & 5 & $0.169 \%$ \\
\hline Virginia & 4 & 42 & $1.416 \%$ \\
\hline Washington & 3 & 31 & $1.045 \%$ \\
\hline
\end{tabular}


West Virginia

Wisconsin

Wyoming

Total

This

reports the number of sample firms by state of incorporation and number of state antitakeover statutes (control share statute, fair price statute, business combination statute, poison pill endorsement statute, and constituencies statute).
$0.034 \%$

$1.079 \%$

$0.034 \%$

$100.000 \%$

1

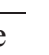


Table 2

Panel B. Descriptive statistics for two-stage analysis.

\begin{tabular}{|c|c|c|c|c|c|c|c|c|c|c|c|c|c|c|c|}
\hline \multirow[b]{2}{*}{ parameter } & \multicolumn{5}{|c|}{ Full sample $(\mathrm{N}=32246)$} & \multicolumn{5}{|c|}{ Home-state subsample $(\mathrm{N}=11176)$} & \multicolumn{5}{|c|}{ Out-of-state subsample $(\mathrm{N}=21070)$} \\
\hline & mean & stdev & $\mathrm{q} 1$ & median & $\mathrm{q} 3$ & mean & stdev & $\mathrm{q} 1$ & median & $\mathrm{q} 3$ & mean & stdev & $\mathrm{q} 1$ & median & q3 \\
\hline FinPerf & 0.026 & 0.143 & 0.023 & 0.056 & 0.080 & 0.040 & 0.118 & 0.035 & 0.060 & 0.081 & 0.019 & 0.153 & 0.016 & 0.053 & 0.079 \\
\hline Return & 0.124 & 0.451 & -0.144 & 0.086 & 0.323 & 0.129 & 0.417 & -0.115 & 0.092 & 0.309 & 0.121 & 0.468 & -0.157 & 0.081 & 0.331 \\
\hline $\log ($ FirmSize $)$ & 7.477 & 1.512 & 6.461 & 7.376 & 8.409 & 7.341 & 1.439 & 6.408 & 7.252 & 8.203 & 7.549 & 1.545 & 6.488 & 7.453 & 8.533 \\
\hline$M / B$ & 2.751 & 2.897 & 1.362 & 2.024 & 3.253 & 2.600 & 2.436 & 1.380 & 1.927 & 3.046 & 2.831 & 3.111 & 1.351 & 2.084 & 3.373 \\
\hline$R \& D \%$ & 0.029 & 0.056 & 0.000 & 0.000 & 0.030 & 0.024 & 0.049 & 0.000 & 0.000 & 0.023 & 0.031 & 0.059 & 0.000 & 0.000 & 0.034 \\
\hline$A d v \operatorname{Exp} \%$ & 0.012 & 0.031 & 0.000 & 0.000 & 0.007 & 0.011 & 0.028 & 0.000 & 0.000 & 0.004 & 0.013 & 0.033 & 0.000 & 0.000 & 0.008 \\
\hline$P P \& E \%$ & 0.292 & 0.238 & 0.098 & 0.233 & 0.435 & 0.307 & 0.251 & 0.098 & 0.247 & 0.464 & 0.283 & 0.230 & 0.098 & 0.226 & 0.421 \\
\hline DepЕхр\% & 0.044 & 0.030 & 0.026 & 0.041 & 0.058 & 0.041 & 0.027 & 0.024 & 0.039 & 0.054 & 0.046 & 0.031 & 0.026 & 0.042 & 0.060 \\
\hline Leverage & 0.236 & 0.186 & 0.081 & 0.220 & 0.348 & 0.218 & 0.169 & 0.075 & 0.202 & 0.333 & 0.246 & 0.194 & 0.086 & 0.230 & 0.357 \\
\hline Home-state Employment & 0.001 & 0.002 & 0.000 & 0.000 & 0.001 & 0.001 & 0.002 & 0.000 & 0.000 & 0.001 & 0.001 & 0.001 & 0.000 & 0.000 & 0.000 \\
\hline Log(OperatingStates $)$ & 2.019 & 0.838 & 1.386 & 2.079 & 2.565 & 1.922 & 0.871 & 1.386 & 1.946 & 2.485 & 2.070 & 0.816 & 1.386 & 2.079 & 2.639 \\
\hline StateLawIndex & 2.028 & 1.569 & 1.000 & 1.000 & 4.000 & 3.370 & 1.502 & 3.000 & 4.000 & 4.000 & 1.317 & 1.054 & 1.000 & 1.000 & 1.000 \\
\hline TAconstraint & 0.403 & 0.490 & 0.000 & 0.000 & 1.000 & 0.939 & 0.239 & 1.000 & 1.000 & 1.000 & 0.118 & 0.323 & 0.000 & 0.000 & 0.000 \\
\hline InState & 0.347 & 0.476 & 0.000 & 0.000 & 1.000 & 1.000 & 0.000 & 1.000 & 1.000 & 1.000 & 0.000 & 0.000 & 0.000 & 0.000 & 0.000 \\
\hline InstiOwn\% & 0.604 & 0.237 & 0.438 & 0.616 & 0.778 & 0.562 & 0.229 & 0.396 & 0.569 & 0.725 & 0.627 & 0.238 & 0.464 & 0.641 & 0.803 \\
\hline Delaware & 0.567 & 0.496 & 0.000 & 1.000 & 1.000 & 0.010 & 0.102 & 0.000 & 0.000 & 0.000 & 0.861 & 0.345 & 1.000 & 1.000 & 1.000 \\
\hline
\end{tabular}

See Table 1 for variable definitions. 
Table 3

Determinants of firms' incorporation choice.

\begin{tabular}{|c|c|}
\hline parameter & estimate \\
\hline Dependent variable & HomeStat \\
\hline \multirow[t]{2}{*}{ Intercept } & 0.077 \\
\hline & $(1.17)$ \\
\hline \multirow[t]{2}{*}{ Home-state Employment } & $99.497 * *$ \\
\hline & (16.98) \\
\hline \multirow[t]{2}{*}{$\log ($ OperatingStates $)$} & $-0.129 * *$ \\
\hline & $(-11.99)$ \\
\hline Home StateLawIndex & $0.221 * * *$ \\
\hline
\end{tabular}

Home TAconstraint

$\log ($ FirmSize)

$-0.143 * * *$

$M / B$

$0.020 * * *$

$R \& D \%$

$0.612 * * *$

$A d v \operatorname{Exp} \%$

$-1.550 * * *$

$P P \& E \%$

$0.723 * * *$

DepExp\%

$-2.583 * * *$

Leverage

$-1.174 * * *$

$(-22.71)$

InstiOwn\%

$-0.389 * * *$

Sample size

Number of firms

Max-rescaled R-Square

0.267

Partial R-square

0.017

1. This table presents the first-stage regression results of the endogenous switching model. The dependent variable HomeState is a dummy variable with a value of 1 if the firm's home state equals its state of incorporation, and zero otherwise. Home-state employment is the ratio of firm i's home state employees (i.e., total employees divided by the number of operating states) to the population of that state in year t-1; $\log$ (OperatingStates) is the natural $\log$ of the number of U.S. states mentioned in the firm's Form 10-K filed with the SEC in year $t-1$; we control for industry and year fixed effects. See Table 1 for other variable definitions.

2. *,**, and *** represent significance at the $10 \%, 5 \%$, and $1 \%$ levels, respectively, for two-tailed tests. 
Dble 4

Regressions of accounting conservatism on state antitakeover laws.

\begin{tabular}{|c|c|c|c|c|c|c|c|c|c|}
\hline parameter & (1) & (2) & (3) & (4) & (5) & (6) & (7) & (8) & (9) \\
\hline & Full & HomeState $=1$ & HomeState $=0$ & HomeState $=1$ & HomeState $=0$ & HomeState $=1$ & HomeState $=0$ & HomeState $=1$ & HomeState $=0$ \\
\hline Dependent variable & FinPerf & FinPerf & FinPerf & FinPerf & FinPerf & FinPerf & FinPerf & FinPerf & FinPerf \\
\hline \multirow[t]{2}{*}{ Intercept } & -0.000 & $0.000 * *$ & -0.000 & $0.000 * *$ & -0.000 & $0.000 * *$ & -0.000 & $0.000 * *$ & -0.000 \\
\hline & $(-0.02)$ & $(2.56)$ & $(-0.03)$ & $(2.52)$ & $(-0.03)$ & $(2.64)$ & $(-0.03)$ & $(2.56)$ & $(-0.03)$ \\
\hline \multirow[t]{2}{*}{ Return } & $-0.104 * * *$ & 0.005 & $-0.073 * * *$ & -0.094 & $-0.069 * * *$ & -0.028 & $-0.089 * * *$ & -0.066 & $-0.074 * * *$ \\
\hline & $(-2.69)$ & $(0.06)$ & $(-5.30)$ & $(-0.94)$ & $(-5.13)$ & $(-0.44)$ & $(-6.03)$ & $(-1.12)$ & $(-5.29)$ \\
\hline \multirow[t]{2}{*}{$\mathrm{Neg}$} & $-0.037 * *$ & -0.044 & $-0.064 * * *$ & -0.065 & $-0.064 * * *$ & -0.055 & $-0.063 * * *$ & -0.051 & $-0.066^{* * *}$ \\
\hline & $(-2.43)$ & $(-0.95)$ & $(-4.15)$ & $(-1.54)$ & $(-4.24)$ & $(-1.26)$ & $(-4.01)$ & $(-1.59)$ & $(-4.71)$ \\
\hline \multirow[t]{2}{*}{ Return*Neg } & $0.748 * * *$ & $0.522 * *$ & $0.511 * * *$ & $0.703 * * *$ & $0.511 * * *$ & $0.560 * * *$ & $0.557 * * *$ & $0.673 * * *$ & $0.541 * * *$ \\
\hline & $(8.52)$ & $(2.57)$ & $(15.14)$ & $(3.01)$ & (14.04) & $(3.33)$ & $(13.91)$ & $(4.23)$ & (12.64) \\
\hline \multirow[t]{2}{*}{ Return*Neg*StateLawIndex } & -0.004 & 0.022 & $-0.024 * *$ & & & & & & \\
\hline & $(-0.54)$ & $(0.51)$ & $(-2.18)$ & & & & & & \\
\hline \multirow[t]{2}{*}{ Return $*$ Neg*StateLawIndex with recap } & & & & -0.012 & $-0.024 *$ & & & & \\
\hline & & & & $(-0.25)$ & $(-1.83)$ & & & & \\
\hline \multirow[t]{2}{*}{ Return*Neg*ThreeLawIndex } & & & & & & 0.023 & $-0.049 * *$ & & \\
\hline & & & & & & $(0.45)$ & $(-2.32)$ & & \\
\hline \multirow[t]{2}{*}{ Return*Neg*BCLaw } & & & & & & & & -0.017 & $-0.049 * *$ \\
\hline & & & & & & & & $(-0.30)$ & $(-2.16)$ \\
\hline \multirow[t]{2}{*}{ Return*Neg*Log(FirmSize $)$} & $-0.047 * * *$ & $-0.033 * *$ & $-0.048 * * *$ & $-0.033 * * *$ & $-0.048 * * *$ & $-0.034 * * *$ & $-0.049 * * *$ & $-0.035^{* * *}$ & $-0.048 * * *$ \\
\hline & $(-8.20)$ & $(-2.64)$ & $(-8.26)$ & $(-2.73)$ & $(-8.38)$ & $(-2.70)$ & $(-8.46)$ & $(-2.79)$ & $(-8.01)$ \\
\hline \multirow[t]{2}{*}{ Return $* N e g * M / B$} & $-0.016^{* * *}$ & $-0.019 * * *$ & $-0.016 * * *$ & $-0.019 * * *$ & $-0.016^{* * *}$ & $-0.019 * * *$ & $-0.016 * * *$ & $-0.019 * * *$ & $-0.016 * * *$ \\
\hline & $(-11.11)$ & $(-3.39)$ & $(-11.42)$ & $(-3.44)$ & $(-11.56)$ & $(-3.38)$ & $(-11.37)$ & $(-3.27)$ & $(-11.31)$ \\
\hline \multirow[t]{2}{*}{ Return*Neg*R\&D\% } & $-0.791 * * *$ & $-0.755^{* *}$ & $-0.764 * * *$ & $-0.727 * *$ & $-0.764 * * *$ & $-0.748 * *$ & $-0.758 * * *$ & $-0.688 * *$ & $-0.747 * * *$ \\
\hline & $(-8.44)$ & $(-2.64)$ & $(-7.08)$ & $(-2.54)$ & $(-7.10)$ & $(-2.59)$ & $(-7.11)$ & $(-2.23)$ & $(-8.18)$ \\
\hline \multirow[t]{2}{*}{ Return $* N e g * A d v \operatorname{Exp} \%$} & 0.203 & 0.162 & $0.361 *$ & 0.174 & 0.358 & 0.165 & $0.356^{*}$ & 0.161 & $0.363^{*}$ \\
\hline & $(1.02)$ & $(0.49)$ & $(1.70)$ & $(0.52)$ & $(1.67)$ & $(0.50)$ & $(1.70)$ & $(0.48)$ & $(1.77)$ \\
\hline Return*Neg*PP\&E\% & $-0.226^{* * *}$ & $-0.402 * * *$ & $-0.166 * * *$ & $-0.403 * * *$ & $-0.167 * * *$ & $-0.392 * * *$ & $-0.161 * * *$ & $-0.388 * * *$ & $-0.170 * * *$ \\
\hline
\end{tabular}




\begin{tabular}{|c|c|c|c|c|c|c|c|c|c|}
\hline & $(-3.02)$ & $(-3.58)$ & $(-2.98)$ & $(-3.61)$ & $(-3.01)$ & $(-3.47)$ & $(-2.98)$ & $(-3.49)$ & $(-2.91)$ \\
\hline \multirow[t]{2}{*}{ Return*Neg*DepExp\% } & $1.293 * * *$ & $1.752 *$ & $1.304 * * *$ & $1.769^{*}$ & $1.305^{* * *}$ & $1.731 *$ & $1.272 * * *$ & $1.697 *$ & $1.346^{* * *}$ \\
\hline & $(5.00)$ & $(1.77)$ & $(9.67)$ & $(1.79)$ & $(9.49)$ & $(1.74)$ & $(8.91)$ & $(1.71)$ & $(10.65)$ \\
\hline \multirow[t]{2}{*}{ Return*Neg*Leverage } & $0.287 * * *$ & $0.450 * * *$ & $0.260 * * *$ & $0.453 * * *$ & $0.260 * * *$ & $0.442 * * *$ & $0.253 * * *$ & $0.429 * * *$ & $0.261 * * *$ \\
\hline & $(6.30)$ & $(4.74)$ & $(8.64)$ & $(4.68)$ & $(8.94)$ & $(4.66)$ & $(8.48)$ & $(4.48)$ & $(8.49)$ \\
\hline \multirow[t]{2}{*}{ Return*Neg*InstiOwn\% } & -0.025 & -0.027 & -0.021 & -0.019 & -0.020 & -0.028 & -0.024 & -0.032 & -0.018 \\
\hline & $(-0.74)$ & $(-0.30)$ & $(-0.80)$ & $(-0.21)$ & $(-0.79)$ & $(-0.31)$ & $(-0.98)$ & $(-0.36)$ & $(-0.65)$ \\
\hline \multirow[t]{2}{*}{ Return*Neg*TAconstraint } & $-0.037^{*}$ & 0.000 & -0.014 & 0.000 & -0.010 & 0.000 & -0.021 & 0.000 & -0.080 \\
\hline & $(-1.71)$ & $(0.00)$ & $(-0.26)$ & $(0.00)$ & $(-0.19)$ & $(0.00)$ & $(-0.40)$ & $(0.00)$ & $(-1.63)$ \\
\hline \multirow[t]{2}{*}{ Return$^{*}$ Neg*InvMills $_{1}$} & & $-0.171 * * *$ & & $-0.181 * * *$ & & $-0.166 * * *$ & & $-0.149 * *$ & \\
\hline & & $(-2.80)$ & & $(-2.95)$ & & $(-2.86)$ & & $(-2.39)$ & \\
\hline \multirow[t]{2}{*}{ Return$^{*}$ Neg $^{*}$ InvMills $_{0}$} & & & -0.025 & & -0.026 & & -0.009 & & -0.029 \\
\hline & & & $(-0.72)$ & & $(-0.77)$ & & $(-0.27)$ & & $(-0.85)$ \\
\hline Sample size & 32246 & 11176 & 21070 & 11176 & 21070 & 11176 & 21070 & 11176 & 21070 \\
\hline R-square & 0.491 & 0.501 & 0.504 & 0.500 & 0.504 & 0.501 & 0.504 & 0.500 & 0.504 \\
\hline
\end{tabular}

1. The dependent variable FinPerf is firm i's earnings before extraordinary items per share (IB) deflated by market value of equity (share price (PRCC F) times common shares outstanding (CSHO) at the beginning of the fiscal year t; Return is firm $i$ 's annual buy-and-hold return measured in year $\mathrm{t}$; Neg is a dummy variable with a value of one if Return <0, and zero otherwise. StateLawIndex is the antitakeover index in year t measured as the number of state antitakeover laws (i.e., control share statute, fair price statute, business combination statute, poison pill endorsement statute, and constituencies statute,) in the state where the firm is incorporated; StateLawIndex with Recap is StateLawIndex plus recapture statute; ThreeLawIndex is the number of control share statute, fair price statute, business combination statute in the state where the firm is incorporated; BCLaw is a dummy variable with a value of 1 if the state has adopted BC law in year $t$ and 0 otherwise. See Table 1 for other variable definitions. In each model, we also include interactions between the Basu elements and year dummies as well as interactions between the Basu elements and state of location dummies. We control for firm and year fixed effects.

2. Column (1) presents the results on the full sample without accounting for the endogeneity of firms' incorporation decisions; Column (2), (4), (6), and (8) present the secondstage results on the home-state incorporation sample after correcting for the endogeneity of firms' incorporation decisions, and Column (3), (5), (7), and (9) present the secondstage results on the out-of-state incorporation sample after correcting for the endogeneity of firms' incorporation decisions.

$3 . *, * * *$, and $* * *$ represent significance at the $10 \%, 5 \%$, and $1 \%$ levels, respectively, for two-tailed tests. Z-statistics using standard errors clustered by state of incorporation are reported in parentheses. 
\$ble 5

Regressions of accounting conservatism on state antitakeover laws: Robustness checks.

\begin{tabular}{|c|c|c|c|c|c|c|c|c|c|c|}
\hline & \multicolumn{8}{|c|}{ The Basu model where Var = Return } & \multirow{2}{*}{\multicolumn{2}{|c|}{$\begin{array}{c}\text { The reversal of earnings } \\
\text { changes model where } \\
\text { Var = Lag(EarnCh) }\end{array}$}} \\
\hline & \multicolumn{2}{|c|}{ Alternative period } & \multicolumn{2}{|c|}{ Control for Delaware } & \multicolumn{2}{|c|}{ Control for BCFatp } & \multicolumn{2}{|c|}{ BHAR } & & \\
\hline & HomeState $=1$ & HomeState $=0$ & HomeState $=1$ & HomeState $=0$ & HomeState $=1$ & HomeState $=0$ & HomeState $=1$ & HomeState $=0$ & HomeState $=1$ & HomeState $=0$ \\
\hline parameter & $(1)$ & $(2)$ & (3) & $(4)$ & $(5)$ & $(6)$ & $(7)$ & $(8)$ & $(9)$ & $(10)$ \\
\hline Dependent variable & FinPerf & FinPerf & FinPerf & FinPerf & FinPerf & FinPerf & FinPerf & FinPerf & EarnCh & EarnCh \\
\hline \multirow[t]{2}{*}{ Intercept } & -0.000 & -0.000 & $0.000 * *$ & -0.000 & $0.000 * *$ & -0.000 & $0.000 * *$ & -0.000 & -0.000 & 0.000 \\
\hline & $(-1.03)$ & $(-0.16)$ & $(2.56)$ & $(-0.03)$ & $(2.45)$ & $(-0.03)$ & $(2.42)$ & $(-0.04)$ & $(-0.63)$ & $(0.15)$ \\
\hline \multirow[t]{2}{*}{ Var } & 0.009 & $-0.037 * * *$ & 0.005 & $-0.109 * * *$ & 0.013 & $-0.065 * * *$ & -0.057 & $-0.072 * * *$ & 0.574 & $0.296 * *$ \\
\hline & $(0.13)$ & $(-2.71)$ & $(0.06)$ & $(-3.08)$ & $(0.17)$ & $(-4.90)$ & $(-0.57)$ & $(-4.30)$ & $(1.62)$ & $(2.46)$ \\
\hline \multirow[t]{2}{*}{$\mathrm{Neg}$} & -0.013 & $-0.052 * * *$ & -0.044 & $-0.075 * * *$ & -0.041 & $-0.064 * * *$ & -0.054 & -0.011 & -0.043 & $-0.041 * * *$ \\
\hline & $(-0.27)$ & $(-3.42)$ & $(-0.95)$ & $(-3.58)$ & $(-0.85)$ & $(-3.40)$ & $(-1.02)$ & $(-0.63)$ & $(-0.97)$ & $(-5.11)$ \\
\hline \multirow[t]{2}{*}{$\operatorname{Var} * \mathrm{Neg}$} & $0.607 * * *$ & $0.519 * * *$ & $0.522 * *$ & $0.598 * * *$ & $0.508 * *$ & $0.497 * * *$ & $0.589 * *$ & $0.591 * * *$ & $-1.917 * *$ & $-1.505 * * *$ \\
\hline & $(3.89)$ & $(16.13)$ & $(2.57)$ & $(6.77)$ & $(2.49)$ & $(14.88)$ & $(2.60)$ & $(9.59)$ & $(-2.02)$ & $(-6.10)$ \\
\hline \multirow[t]{2}{*}{ Var*Neg*StateLawIndex } & 0.005 & $-0.019 *$ & 0.022 & $-0.033 *$ & 0.023 & $-0.024 * *$ & 0.011 & $-0.029 * * *$ & 0.039 & $0.190 * * *$ \\
\hline & $(\mathbf{0 . 1 7})$ & $(-1.86)$ & $(\mathbf{0 . 5 1})$ & $(-1.81)$ & $(\mathbf{0 . 5 3})$ & $(-2.17)$ & $(\mathbf{0 . 2 0})$ & $(-3.37)$ & $(0.47)$ & $(2.99)$ \\
\hline \multirow[t]{2}{*}{ Var*Neg*Log (FirmSize $)$} & $-0.033 * * *$ & $-0.048 * * *$ & $-0.033 * *$ & $-0.048 * * *$ & $-0.033 * *$ & $-0.048 * * *$ & $-0.028 *$ & $-0.047 * * *$ & $0.171 * * *$ & $0.143 * * *$ \\
\hline & $(-2.69)$ & $(-8.76)$ & $(-2.64)$ & $(-8.19)$ & $(-2.65)$ & $(-7.86)$ & $(-1.84)$ & $(-7.98)$ & $(3.75)$ & $(18.47)$ \\
\hline \multirow[t]{2}{*}{$\operatorname{Var} * N e g * M / B$} & $-0.021 * * *$ & $-0.017 * * *$ & $-0.019 * * *$ & $-0.016 * * *$ & $-0.019 * * *$ & $-0.015 * * *$ & -0.010 & $-0.008 * * *$ & 0.001 & $0.001 * * *$ \\
\hline & $(-3.66)$ & $(-13.87)$ & $(-3.39)$ & $(-11.42)$ & $(-3.23)$ & $(-11.04)$ & $(-1.64)$ & $(-6.66)$ & $(0.26)$ & $(10.82)$ \\
\hline \multirow[t]{2}{*}{ Var*Neg*R\&D\% } & $-0.706 * *$ & $-0.743 * * *$ & $-0.755 * *$ & $-0.759 * * *$ & $-0.764 * * *$ & $-0.759 * * *$ & $-0.685^{* * *}$ & $-0.497 * * *$ & 0.661 & $-0.960 * * *$ \\
\hline & $(-2.51)$ & $(-6.69)$ & $(-2.64)$ & $(-7.28)$ & $(-2.68)$ & $(-7.12)$ & $(-3.46)$ & $(-4.18)$ & $(0.82)$ & $(-8.94)$ \\
\hline \multirow[t]{2}{*}{ Var*Neg*AdvExp\% } & 0.160 & 0.248 & 0.162 & 0.357 & 0.166 & $0.375^{*}$ & -0.423 & $0.656^{* *}$ & 0.559 & 0.341 \\
\hline & $(0.46)$ & $(1.20)$ & $(0.49)$ & $(1.67)$ & $(0.50)$ & $(1.84)$ & $(-1.06)$ & $(2.21)$ & $(0.59)$ & $(1.10)$ \\
\hline \multirow[t]{2}{*}{ Var*Neg*PP\&E\% } & $-0.390 * * *$ & $-0.165 * * *$ & $-0.402 * * *$ & $-0.168 * * *$ & $-0.404 * * *$ & $-0.171 * * *$ & $-0.336 * * *$ & $-0.102 * *$ & -0.639 & $-0.843 * * *$ \\
\hline & $(-3.62)$ & $(-3.41)$ & $(-3.58)$ & $(-2.93)$ & $(-3.53)$ & $(-2.90)$ & $(-3.97)$ & $(-2.12)$ & $(-1.25)$ & $(-9.28)$ \\
\hline \multirow[t]{2}{*}{ Var*Neg*DepExp\% } & $1.659^{*}$ & $1.235 * * *$ & $1.752 *$ & $1.310 * * *$ & $1.754^{*}$ & $1.339 * * *$ & 0.905 & $1.145^{* * *}$ & 2.741 & $1.181 * * *$ \\
\hline & $(1.71)$ & $(7.00)$ & $(1.77)$ & $(9.89)$ & $(1.73)$ & (10.59) & $(0.99)$ & $(8.59)$ & $(0.68)$ & $(19.10)$ \\
\hline \multirow[t]{2}{*}{ Var*Neg*Leverage } & $0.451 * * *$ & $0.272 * * *$ & $0.450 * * *$ & $0.260 * * *$ & $0.445 * * *$ & $0.259 * * *$ & $0.325 * * *$ & $0.258 * * *$ & -0.134 & $-0.342 * * *$ \\
\hline & $(5.02)$ & $(9.25)$ & $(4.74)$ & $(8.53)$ & $(4.57)$ & $(8.49)$ & $(4.41)$ & $(10.01)$ & $(-0.32)$ & $(-3.74)$ \\
\hline
\end{tabular}




\begin{tabular}{|c|c|c|c|c|c|c|c|c|c|c|}
\hline \multirow[t]{2}{*}{ Var*Neg*InstiOwn\% } & -0.021 & -0.018 & -0.027 & -0.021 & -0.032 & -0.028 & -0.024 & $-0.072 * * *$ & 0.029 & -0.082 \\
\hline & $(-0.24)$ & $(-0.70)$ & $(-0.30)$ & $(-0.82)$ & $(-0.35)$ & $(-1.12)$ & $(-0.29)$ & $(-4.11)$ & $(0.11)$ & $(-1.30)$ \\
\hline \multirow[t]{2}{*}{ Var*Neg*TAconstraint } & 0.000 & -0.033 & 0.000 & -0.063 & 0.000 & -0.009 & 0.000 & -0.001 & 0.000 & $-0.629 * * *$ \\
\hline & $(0.00)$ & $(-0.68)$ & $(0.00)$ & $(-1.10)$ & $(0.00)$ & $(-0.18)$ & (.) & $(-0.04)$ & (.) & $(-3.36)$ \\
\hline \multirow[t]{2}{*}{ Var*Neg*Delaware } & & & 0.000 & -0.076 & & & & & & \\
\hline & & & $(0.00)$ & $(-1.14)$ & & & & & & \\
\hline \multirow[t]{2}{*}{ Var*Neg*BCFatp } & & & & & 0.007 & 0.010 & & & & \\
\hline & & & & & $(0.60)$ & $(1.18)$ & & & & \\
\hline \multirow[t]{2}{*}{ Var*Neg*InvMills1 } & $-0.173 * * *$ & & $-0.171 * * *$ & & $-0.167 * * *$ & & $-0.120 * *$ & & $-0.692 * * *$ & \\
\hline & $(-3.02)$ & & $(-2.80)$ & & $(-2.73)$ & & $(-2.02)$ & & $(-2.77)$ & \\
\hline \multirow[t]{2}{*}{ Var*Neg*InvMillsO } & & -0.016 & & -0.025 & & -0.021 & & -0.036 & & 0.106 \\
\hline & & $(-0.49)$ & & $(-0.70)$ & & $(-0.61)$ & & $(-1.17)$ & & $(1.05)$ \\
\hline Sample size & 12079 & 22649 & 11176 & 21070 & 11176 & 21070 & 11176 & 21070 & 10809 & 20290 \\
\hline R-square & 0.500 & 0.495 & 0.501 & 0.504 & 0.501 & 0.504 & 0.490 & 0.496 & 0.299 & 0.316 \\
\hline
\end{tabular}

1. In Columns (1) through (8), the dependent variable FinPerf is firm i's earnings before extraordinary items per share (IB) deflated by market value of equity (share price (PRCC_F) times common shares outstanding (CSHO) at the beginning of the fiscal year $\mathrm{t}$; Var is Return, firm $i$ 's annual buy-and-hold return measured in year $\mathrm{t}$; Neg is a dummy variable with a value of one if Return $<0$, and zero otherwise. In Columns (9) and (10), the dependent variable EarnCh is the change in net income before extraordinary items (IB) between year $t-1$ and year $t$, deflated by total assets (AT) at the beginning of the year t-1; Var is Lag (EarnCh), that is, EarnCh in the previous year (i.e., earnings changes between year t-2 and year t-1). StateLawIndex is the antitakeover index in year t measured as the number of state antitakeover laws (i.e., control share statute, fair price statute, business combination statute, poison pill endorsement statute, and constituencies statute, ) in the state where the firm is incorporated; See Table 1 for other variable definitions. In each model, we also include interactions between the Basu elements and year dummies as well as interactions between the Basu elements and state of location dummies. We control for firm and year fixed effects.

2. Column (1) through (8) report sensitivity test results using the Basu measure as a proxy for conservatism. Column (9) and (10) report sensitivity test results using the reversal of earnings changes as a proxy for conservatism.

3 . $*, * * *$, and $* * *$ represent significance at the $10 \%, 5 \%$, and $1 \%$ levels, respectively, for two-tailed tests. Z-statistics using standard errors clustered by state of incorporation are reported in parentheses. 
Table 6

Panel A. Replication of Jayaraman and Shivakumar (2013): descriptive statistics.

\begin{tabular}{lcccccccc}
\hline \multicolumn{1}{c}{ parameter } & $\mathrm{n}$ & mean & stdev & $\min$ & $\max$ & $\mathrm{q} 1$ & median & $\mathrm{q} 3$ \\
\hline FinPerf & 32856 & 0.070 & 0.136 & -0.830 & 0.438 & 0.035 & 0.082 & 0.136 \\
Return & 32856 & 0.179 & 0.448 & -0.701 & 2.441 & -0.103 & 0.120 & 0.375 \\
Neg & 32856 & 0.357 & 0.479 & 0.000 & 1.000 & 0.000 & 0.000 & 1.000 \\
AfterLaw & 32856 & 0.365 & 0.481 & 0.000 & 1.000 & 0.000 & 0.000 & 1.000 \\
Log(FirmSize) & 32856 & 5.275 & 2.062 & 0.901 & 9.944 & 3.729 & 5.203 & 6.830 \\
M/B & 32856 & 2.027 & 2.062 & 0.344 & 14.339 & 0.932 & 1.420 & 2.283 \\
PrcInv & 32856 & 0.164 & 0.348 & 0.012 & 2.667 & 0.035 & 0.061 & 0.133 \\
\hline
\end{tabular}

Table 6

Panel B. The coefficient on Return*Neg by sub-period

\begin{tabular}{cc}
\hline Sub-period & Estimate \\
\hline $1976-1980$ & $0.322^{* * *}$ \\
& $(16.57)$ \\
$1981-1985$ & $0.200^{* * *}$ \\
& $(16.09)$ \\
$1986-1990$ & $0.257 * * *$ \\
& $(22.18)$ \\
$1991-1995$ & $0.316^{* * *}$ \\
& $(21.88)$ \\
\hline
\end{tabular}


Dble 7

Replication of Jayaraman and Shivakumar (2013) Table 7 and controlling for economy-wide trends in conservatism.

\begin{tabular}{|c|c|c|c|c|c|c|c|c|}
\hline parameter & (1) & (2) & (3) & (4) & (5) & (6) & (7) & (8) \\
\hline Dependent variable & Finperf & Finperf & Finperf & Finperf & Finperf & Finperf & Finperf & Finperf \\
\hline \multirow[t]{2}{*}{ Intercept } & $0.150 * * *$ & $0.157 * * *$ & $0.149 * * *$ & 0.005 & $-0.000 * * *$ & $-0.000 * * *$ & $-0.000 * * *$ & $-0.000 * * *$ \\
\hline & (15.39) & $(16.25)$ & $(11.91)$ & $(0.70)$ & $(-3.74)$ & $(-3.01)$ & $(-3.53)$ & $(-4.25)$ \\
\hline \multirow[t]{2}{*}{ Return } & $0.088 * * *$ & $0.088 * * *$ & $0.122 * * *$ & $0.071 * * *$ & $0.099 * * *$ & $0.099 * * *$ & $0.137 * * *$ & $0.102 * * *$ \\
\hline & $(9.46)$ & $(9.48)$ & $(7.22)$ & $(7.45)$ & $(8.59)$ & $(8.62)$ & (8.90) & (10.69) \\
\hline \multirow[t]{2}{*}{$\mathrm{Neg}$} & $-0.017 *$ & -0.013 & -0.006 & $-0.022 * *$ & $-0.013 * *$ & $-0.009 *$ & 0.001 & -0.007 \\
\hline & $(-2.01)$ & $(-1.57)$ & $(-0.55)$ & $(-2.35)$ & $(-2.57)$ & $(-1.81)$ & $(0.06)$ & $(-0.99)$ \\
\hline \multirow[t]{2}{*}{ Return*Neg } & $0.415 * * *$ & $0.393 * * *$ & $0.348 * * *$ & $0.231 * * *$ & $0.328 * * *$ & $0.281 * * *$ & $0.236 * * *$ & 0.079 \\
\hline & (10.38) & (6.19) & $(4.88)$ & (4.16) & $(8.28)$ & $(4.66)$ & (3.54) & (1.57) \\
\hline \multirow[t]{2}{*}{ AfterLaw } & $-0.009 *$ & $-0.013 * *$ & -0.008 & -0.009 & -0.006 & $-0.010 * *$ & -0.003 & -0.004 \\
\hline & $(-1.86)$ & $(-2.59)$ & $(-1.25)$ & $(-1.53)$ & $(-1.39)$ & $(-2.22)$ & $(-0.54)$ & $(-0.70)$ \\
\hline \multirow[t]{2}{*}{ AfterLaw*Return } & 0.005 & 0.005 & -0.004 & -0.000 & 0.001 & 0.001 & -0.011 & -0.006 \\
\hline & $(1.26)$ & $(1.10)$ & $(-0.30)$ & $(-0.03)$ & $(0.34)$ & $(0.27)$ & $(-0.77)$ & $(-0.48)$ \\
\hline \multirow[t]{2}{*}{ AfterLaw*Neg } & $0.017 * * *$ & $0.016 * * *$ & -0.000 & 0.002 & $0.012 * * *$ & $0.011 * * *$ & -0.009 & -0.006 \\
\hline & $(4.98)$ & $(4.75)$ & $(-0.00)$ & $(0.25)$ & $(3.89)$ & $(3.49)$ & $(-1.05)$ & $(-0.69)$ \\
\hline \multirow[t]{2}{*}{ AfterLaw*Return*Neg } & $0.052 * *$ & 0.003 & -0.016 & -0.015 & $0.037 * *$ & -0.007 & -0.028 & -0.029 \\
\hline & (2.19) & $(0.09)$ & $(-0.28)$ & $(-0.27)$ & (2.16) & $(-0.22)$ & $(-0.63)$ & $(-0.65)$ \\
\hline \multirow[t]{2}{*}{$\log ($ FirmSize $)$} & $0.004 * * *$ & $0.004 * * *$ & $0.004 * * *$ & & $0.014 * * *$ & $0.013 * * *$ & $0.015 * * *$ & \\
\hline & $(3.82)$ & $(3.95)$ & $(3.87)$ & & $(5.40)$ & $(5.18)$ & $(5.84)$ & \\
\hline \multirow[t]{2}{*}{ Log $($ FirmSize $) *$ Return } & $-0.003 *$ & $-0.004 *$ & $-0.004 *$ & & -0.003 & -0.004 & -0.004 & \\
\hline & $(-1.74)$ & $(-1.83)$ & $(-1.70)$ & & $(-1.46)$ & $(-1.54)$ & $(-1.46)$ & \\
\hline \multirow[t]{2}{*}{$\log ($ FirmSize $) * N e g$} & -0.001 & -0.001 & -0.001 & & -0.001 & -0.001 & -0.001 & \\
\hline & $(-0.53)$ & $(-0.70)$ & $(-1.05)$ & & $(-0.87)$ & $(-1.12)$ & $(-1.08)$ & \\
\hline \multirow[t]{2}{*}{$\log ($ FirmSize $) *$ Return $* N e g$} & $-0.039 * * *$ & $-0.039 * * *$ & $-0.039 * * *$ & & $-0.034 * * *$ & $-0.035 * * *$ & $-0.034 * * *$ & \\
\hline & $(-7.10)$ & $(-7.18)$ & $(-7.22)$ & & $(-6.15)$ & $(-6.20)$ & $(-5.94)$ & \\
\hline \multirow[t]{2}{*}{$M / B$} & $-0.008 * * *$ & $-0.008 * * *$ & $-0.008 * * *$ & $-0.007 * * *$ & $0.001 *$ & $0.002 *$ & $0.002 * *$ & $0.005 * * *$ \\
\hline & $(-11.88)$ & $(-11.24)$ & $(-10.25)$ & $(-11.32)$ & $(1.76)$ & (1.98) & $(2.23)$ & $(5.84)$ \\
\hline \multirow[t]{2}{*}{$M / B *$ Return } & $-0.008 * * *$ & $-0.008 * * *$ & $-0.008 * * *$ & $-0.007 * * *$ & $-0.008 * * *$ & $-0.008 * * *$ & $-0.008 * * *$ & $-0.008 * * *$ \\
\hline & $(-7.66)$ & $(-7.29)$ & $(-6.44)$ & $(-5.21)$ & $(-10.28)$ & $(-9.82)$ & $(-8.29)$ & $(-8.16)$ \\
\hline \multirow[t]{2}{*}{$M / B * N e g$} & $0.003 * * *$ & $0.003 * * *$ & $0.003 * * *$ & $0.004 * * *$ & $0.002 * * *$ & $0.002 * * *$ & $0.002 * *$ & $0.003 * * *$ \\
\hline & $(3.71)$ & $(3.65)$ & $(3.23)$ & $(3.20)$ & $(3.29)$ & $(3.13)$ & $(2.65)$ & $(4.08)$ \\
\hline \multirow[t]{2}{*}{$M / B^{*} \operatorname{Return} * N e g$} & $-0.014 * * *$ & $-0.013 * * *$ & $-0.013 * * *$ & $-0.014 * * *$ & $-0.008 * * *$ & $-0.007 * *$ & $-0.008 * *$ & $-0.009 * * *$ \\
\hline & $(-5.82)$ & $(-5.20)$ & $(-4.90)$ & $(-4.59)$ & $(-3.09)$ & $(-2.55)$ & $(-2.51)$ & $(-2.82)$ \\
\hline \multirow[t]{2}{*}{ PrcInv } & $-0.063 * * *$ & $-0.063 * * *$ & $-0.062 * * *$ & & $-0.046^{* * *}$ & $-0.046 * * *$ & $-0.045 * * *$ & \\
\hline & $(-14.33)$ & $(-14.65)$ & $(-13.29)$ & & $(-8.23)$ & $(-8.17)$ & $(-7.52)$ & \\
\hline \multirow[t]{2}{*}{ PrcInv*Return } & $-0.023 * * *$ & $-0.023 * * *$ & $-0.024 * * *$ & & $-0.019 * *$ & $-0.019 * *$ & $-0.020 * * *$ & \\
\hline & $(-3.05)$ & $(-3.01)$ & $(-3.24)$ & & $(-2.37)$ & $(-2.39)$ & $(-2.70)$ & \\
\hline
\end{tabular}




\begin{tabular}{|c|c|c|c|c|c|c|c|c|}
\hline $\operatorname{PrcInv} * \mathrm{Neg}$ & $\begin{array}{c}-0.031 * * * \\
(-4.07)\end{array}$ & $\begin{array}{c}-0.031 * * * \\
(-4.31)\end{array}$ & $\begin{array}{c}-0.033 * * * \\
(-4.69)\end{array}$ & & $\begin{array}{c}-0.021 * * * \\
(-3.08)\end{array}$ & $\begin{array}{c}-0.022 * * * \\
(-3.07)\end{array}$ & $\begin{array}{c}-0.024 * * * \\
(-3.47)\end{array}$ & \\
\hline \multirow[t]{2}{*}{$\operatorname{PrcInv} *$ Return*Neg } & $-0.131 * * *$ & $-0.136 * * *$ & $-0.137 * * *$ & & $-0.096^{* * *}$ & $-0.097 * * *$ & $-0.099 * * *$ & \\
\hline & $(-4.43)$ & $(-4.74)$ & $(-4.87)$ & & $(-3.15)$ & $(-3.17)$ & $(-3.39)$ & \\
\hline \multirow[t]{2}{*}{ yearcdum1976*Return $* N e g$} & & $0.198 * * *$ & 0.060 & 0.049 & & $0.211 * * *$ & 0.115 & 0.131 \\
\hline & & $(2.78)$ & $(0.57)$ & $(0.47)$ & & $(3.25)$ & $(1.16)$ & $(1.35)$ \\
\hline \multirow[t]{2}{*}{ yearcdum $1977 *$ Return $*$ Neg } & & $0.108 * *$ & 0.056 & 0.017 & & $0.155^{* * *}$ & 0.078 & 0.056 \\
\hline & & $(2.50)$ & $(0.70)$ & $(0.20)$ & & $(3.49)$ & $(0.99)$ & $(0.71)$ \\
\hline \multirow[t]{2}{*}{ yearcdum1978*Return*Neg } & & $0.092 *$ & $0.157 * *$ & 0.119 & & $0.126^{* * *}$ & $0.130^{*}$ & $0.121^{*}$ \\
\hline & & $(1.76)$ & $(2.03)$ & $(1.54)$ & & $(2.70)$ & $(1.97)$ & $(1.76)$ \\
\hline \multirow[t]{2}{*}{ yearcdum 1979*Return*Neg } & & 0.041 & 0.084 & 0.068 & & 0.077 & 0.090 & 0.083 \\
\hline & & $(0.75)$ & $(1.18)$ & $(0.92)$ & & $(1.47)$ & $(1.21)$ & $(1.12)$ \\
\hline \multirow[t]{2}{*}{ yearcdum $1980 *$ Return*Neg } & & 0.075 & $0.196^{* *}$ & $0.193 * *$ & & $0.105^{* *}$ & $0.180 * *$ & $0.179 * *$ \\
\hline & & $(1.37)$ & $(2.52)$ & $(2.50)$ & & $(2.01)$ & $(2.42)$ & $(2.45)$ \\
\hline \multirow[t]{2}{*}{ yearcdum1981*Return $*$ Neg } & & $0.067 *$ & 0.094 & 0.026 & & $0.109 * * *$ & $0.150 * *$ & $0.099 *$ \\
\hline & & $(1.86)$ & $(1.55)$ & $(0.46)$ & & $(3.20)$ & $(2.61)$ & $(1.89)$ \\
\hline \multirow[t]{2}{*}{ yearcdum $1982 *$ Return $* N e g$} & & -0.021 & 0.045 & 0.014 & & 0.018 & $0.105^{* *}$ & $0.084^{*}$ \\
\hline & & $(-0.48)$ & $(0.74)$ & $(0.24)$ & & $(0.47)$ & $(2.14)$ & $(1.70)$ \\
\hline \multirow[t]{2}{*}{ yearcdum1983*Return*Neg } & & 0.016 & 0.065 & 0.064 & & 0.041 & $0.132 * *$ & 0.107 \\
\hline & & $(0.37)$ & $(0.96)$ & $(0.96)$ & & $(0.95)$ & $(2.01)$ & $(1.55)$ \\
\hline \multirow[t]{2}{*}{ yearcdum1984*Return*Neg } & & -0.002 & -0.012 & -0.040 & & 0.026 & 0.031 & -0.004 \\
\hline & & $(-0.05)$ & $(-0.23)$ & $(-0.80)$ & & $(0.77)$ & $(0.63)$ & $(-0.07)$ \\
\hline \multirow[t]{2}{*}{ yearcdum $1985 *$ Return $* N e g$} & & 0.042 & 0.081 & 0.038 & & 0.049 & 0.113 & 0.081 \\
\hline & & $(0.84)$ & $(1.08)$ & $(0.56)$ & & $(0.95)$ & $(1.51)$ & $(1.13)$ \\
\hline \multirow[t]{2}{*}{ yearcdum1986*Return*Neg } & & $0.078^{*}$ & $0.103^{* *}$ & $0.090^{*}$ & & $0.070^{*}$ & $0.097 * *$ & 0.076 \\
\hline & & $(1.95)$ & $(2.11)$ & $(1.85)$ & & $(1.80)$ & $(2.08)$ & $(1.63)$ \\
\hline \multirow[t]{2}{*}{ yearcdum1987*Return*Neg } & & $-0.058^{*}$ & 0.023 & 0.013 & & -0.018 & 0.038 & 0.031 \\
\hline & & $(-1.95)$ & $(0.62)$ & $(0.36)$ & & $(-0.57)$ & $(1.05)$ & $(0.95)$ \\
\hline \multirow[t]{2}{*}{ yearcdum1989*Return*Neg } & & $0.110^{* * *}$ & $0.169 * * *$ & $0.153 * * *$ & & $0.105^{* * *}$ & $0.176^{* * *}$ & $0.180^{* * *}$ \\
\hline & & $(3.57)$ & $(3.59)$ & $(3.81)$ & & $(3.23)$ & $(4.26)$ & $(4.52)$ \\
\hline \multirow[t]{2}{*}{ yearcdum1990*Return*Neg } & & 0.041 & $0.147 * * *$ & $0.130 * * *$ & & $0.070 * *$ & $0.155^{* * *}$ & $0.155^{* * *}$ \\
\hline & & $(1.50)$ & $(3.11)$ & $(3.01)$ & & $(2.38)$ & $(3.71)$ & $(3.80)$ \\
\hline \multirow[t]{2}{*}{ yearcdum1991*Return*Neg } & & $0.115^{* * *}$ & $0.175^{* * *}$ & $0.153 * * *$ & & $0.142 * * *$ & $0.224 * * *$ & $0.222 * * *$ \\
\hline & & $(3.32)$ & $(3.58)$ & $(3.37)$ & & $(4.33)$ & $(6.57)$ & $(6.74)$ \\
\hline \multirow[t]{2}{*}{ yearcdum 1992*Return*Neg } & & $0.121 * * *$ & $0.151 * * *$ & $0.132 * * *$ & & $0.112 * * *$ & $0.166^{* * *}$ & $0.155 * * *$ \\
\hline & & $(4.42)$ & $(3.40)$ & $(3.01)$ & & $(3.42)$ & $(3.59)$ & $(3.08)$ \\
\hline \multirow[t]{2}{*}{ yearcdum 1993*Return*Neg } & & $0.076^{*}$ & 0.104 & 0.068 & & $0.089 * *$ & $0.103^{*}$ & 0.077 \\
\hline & & $(1.89)$ & $(1.52)$ & $(0.97)$ & & $(2.46)$ & $(1.78)$ & $(1.29)$ \\
\hline \multirow[t]{2}{*}{ yearcdum1994*Return*Neg } & & 0.047 & $0.140 * * *$ & $0.122 * * *$ & & $0.088 * *$ & $0.157 * * *$ & $0.142 * * *$ \\
\hline & & $(1.31)$ & $(3.12)$ & $(2.69)$ & & $(2.50)$ & $(3.84)$ & $(3.50)$ \\
\hline \multirow[t]{2}{*}{ yearcdum1995*Return*Neg } & & $0.138 * * *$ & $0.218 * * *$ & $0.196 * * *$ & & $0.161 * * *$ & $0.256 * * *$ & $0.255^{* * *}$ \\
\hline & & $(4.51)$ & $(4.73)$ & $(5.17)$ & & $(4.73)$ & $(5.46)$ & $(5.68)$ \\
\hline Firm fixed effects & No & No & No & No & Yes & Yes & Yes & Yes \\
\hline
\end{tabular}




\begin{tabular}{|c|c|c|c|c|c|c|c|c|}
\hline Year fixed effects & Yes & Yes & Yes & Yes & Yes & Yes & Yes & Yes \\
\hline $\begin{array}{l}\text { Incorporation state fixed } \\
\text { effects }\end{array}$ & Yes & Yes & Yes & Yes & No & No & No & No \\
\hline $\begin{array}{l}\text { Interactions between year } \\
\text { dummies and Return }\end{array}$ & No & No & Yes & Yes & No & No & Yes & Yes \\
\hline $\begin{array}{l}\text { Interactions between year } \\
\text { dummies and } \mathrm{Neg}\end{array}$ & No & No & Yes & Yes & No & No & Yes & Yes \\
\hline Sample size & 32856 & 32856 & 32856 & 32856 & 32856 & 32856 & 32856 & 32856 \\
\hline R-square & 0.356 & 0.359 & 0.362 & 0.312 & 0.490 & 0.492 & 0.496 & 0.481 \\
\hline
\end{tabular}

1. Column (1) and (5) present the baseline results of replicating Table 7 of Jayaraman and Shivakumar (2013) Table 7.

Columns (2) and (6) modify the corresponding baseline models by including the interactions of year dummies with

Return*Neg; Columns (3) and (7) modify the corresponding baseline models by including the interactions of year dummies with all the three Basu elements (i.e., Return, Neg, and Return*Neg). Columns (4) and (8) modify the models in columns (3) and (7) further by excluding the interactions of $\log$ (FirmSize) with all the three Basu elements (Return, Neg, and Return*Neg) and the interactions of PrcInv with all the three Basu elements. See Table 1 for variable definitions. $2 . * * *$, and $* * *$ represent significance at the $10 \%, 5 \%$, and $1 \%$ levels, respectively, for two-tailed tests. Z-statistics using standard errors clustered by state of incorporation are reported in parentheses. 
Slope coefficient of Return*Neg over the period 1976 - 1995

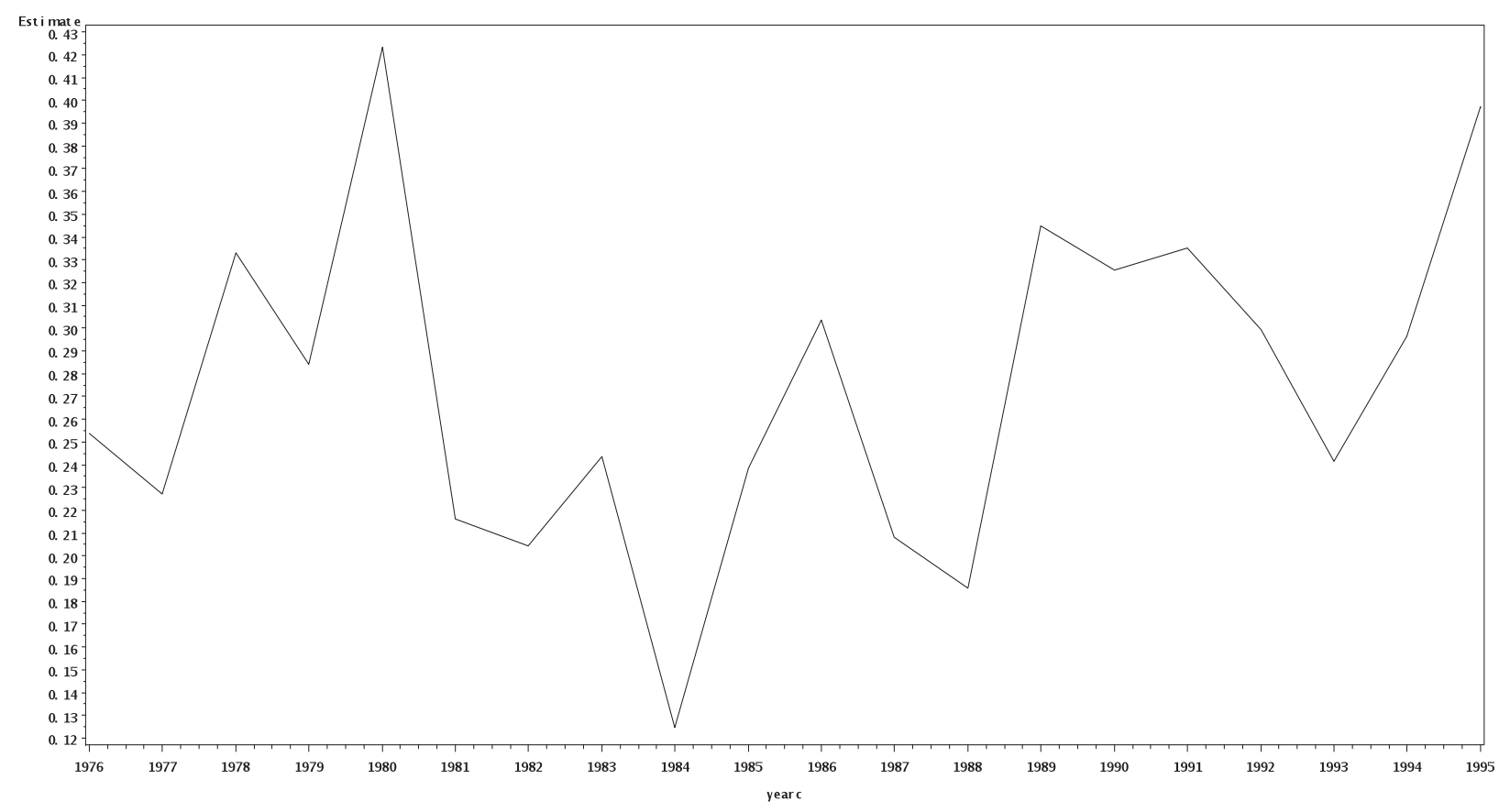

Fig. 1. 